\title{
Değer Eğitimi Sürecinde Okul - Aile İşbirliği: Bir Nitel Çalışma
}

\section{School - Family Cooperation in the Value Education Process: A Qualitative Study}

\author{
Zeliha AKIN, Sorumlu Yazar, Öğretmen. \\ T.C. Milli Eğitim Bakanlı̆̆ı, Kayseri / Türkiye \\ zelis38@gmail.com \\ https://orcid.org/0000-0001-9430-1039 \\ Ergün ÖZTÜRK, Prof. Dr. \\ Erciyes Üniversitesi, Eğitim Fakültesi, Kayseri / Türkiye. \\ erg2424@gmail.com \\ https://orcid.org/0000-0002-4800-8437
}

ISSN: 1303-880X

e-ISSN: 2667-7504

http://ded.dem.org.tr

Makale Türü / Article Type:

Araştırma Makalesi / Research Article

Geliş Tarihi / Received Date: 11.04.2021

Kabul Tarihi / Accepted Date: 20.06.2021

Yayın Tarihi / Published Date: 25.12.2021

Tr/En: $\operatorname{Tr}$

Intihal / Plagiarism: Bu makale, en az iki hakem tarafindan incelendi ve intihal içermediği teyit edildi. / This article has been reviewed by at least two referees and scanned via a plagiarism software.

Attf/Citation: Akın, Z. \& Öztürk, E. (2021). Değer eğitimi sürecinde okul - aile işbirliği: Bir nitel çalışma. Değerler Eğitimi Dergisi, 19 (42), s.73-112

https://doi.org/10.34234/ded.912583 
Öz: Bu araştırmanın amacı değer eğitiminde okul - aile işbirliğini değerlendirmek ve değer kazandırma sürecinde bu işbirliğinin önemini belirlemektir. Değerler eğitiminde okul ve aile işbirliğinin önemi hakkında derinlemesine bilgi etmek için nitel araştırma deseni benimsenmiştir. Çalışma grubunu Kayseri il merkezinde bulunan bir devlet okulunda 5. Sınıf derslerine giren 10 öğretmen ve 5. Sınıfta öğrencisi bulunan 10 veli oluşturmaktadır. Katılımcılar amaçsal örneklem yöntemi ile belirlenmiştir. Elde edilen veriler yarı yapılandırılmış görüşme formu kullanılarak raporlanmıştır. Görüşmeler ses kaydı ile alınmış, daha sonra her bir görüşmenin ses kaydı çözümlenmiş, elde edilen kodlar ve temalar tablolar halinde sunulmuştur. Bulgulara göre öğretmen ve velilerin değer tanımları benzerlik gösterdiği tespit edilmiştir. Araştırma sonuçlarına göre hem öğretmenler hem veliler öncelikli olarak dürüstlük, saygı ve sevgi değerlerinin öğretilmesi gerektiğini düşünmektedirler. Öğretmenlerden elde edilen görüşlere göre kazandırmakta zorluk çekilen değerler en çok dürüstlük, saygı ve paylaşma olurken veliler ise en çok dürüstlük ve sorumluluk değerlerini kazandırmakta zorluk çektiklerini belirtmişlerdir. Veliler ve öğretmenler birbirlerinden en çok dürüstlük, sayg1 ve sevgi değerlerini öğretmelerini beklemektedirler. Öğretmenlerin değer kazandırırken en çok model olma ve yaşantılardan örnekler verme yöntemlerini kullandığını; velilerin ise en çok ögüt verme, model olma ve yaşantılardan örnekler verme yöntemlerini kullandıklarını göstermektedir.

Anahtar Kelimeler: Değer eğitimi, Okul-Aile işbirliği, Aile katılımı.

\section{$\&$}

Abstract: This study aims to evaluate the school-family cooperation in value education and determine the importance of this cooperation in the process of teaching values. In this study, a qualitative research design is used. The study group consists of ten teachers of 5th-grade classes and ten parents of students in 5th grade in a public school in Kayseri. Participants were chosen by a purposeful sampling method. The data were collected using a semi-structured interview form. The interviews were recorded by audio recording, then the audio recording of each interview was analyzed, the codes and themes were presented in tables. The results of the study indicated that value definitions of the achers and parents were simillar. Both teachers and parents think that honesty, respect, and love should be given priority. Also, teachers think that they have difficulty in teaching honesty, respect, and sharing while the parents state these values like honesty and responsibility. Parents and teachers expect each others to teach 
honesty, respect, and love. The results of the research show that whike teachers mostly use methods like; being a model and giving examples from experiences, parents generally use the ways of giving advice, being a model, and giving examples from their lives.

Keywords: Value education, School-Parents cooperation, Family participation. (The Extended Abstract is at the end of the article)

\section{Giriş}

Değerler yaptığımız seçimleri, aldığımız kararları, ilişkilerimizi etkileyerek yaşamımızı şekillendirir. Sahip olduğumuz değerler toplumla nasıl ilişki kurduğumuzu belirler. Değerler hem bireysel hem toplumsal yaşamımızı düzenler. Günümüzde hemen her alanda yaşanan gelişmeler ve ortaya çıkan değişiklikler hayatımızı kolaylaştırmakla beraber hem özel hem toplumsal yaşamda bazı sıkıntıları da beraberinde getirmektedir. Maddi değerlerin manevi değerlerin önüne geçmesi, insanların daha fazla bireyselleşmesi ve bencilleşmesi, insanların istedikleri şeyleri kolay yoldan elde etmeye çalışması, aile bağlarının zayıflaması, geleneklere bağlılığın azalması, daha farklı ve modern bir hayat yaşama çabası değerlerin önemini yitirmesine dolayısıyla toplumsal yapının bozulmasına sebep olmuştur (Aydın, 2011; Pala, 2011; Çağlayan, 2018; Eren, 2018; Koç \& Akdoğan, 2018). Değerleri bilmek, doğru ve yanlış davranışları ayırt etmemizi hem kendi yaşamımız hem de toplumsal düzen için sahip olmamız gereken olumlu özellikleri geliştirmemizi, bu yönde kararlar almamızı ve hareket etmemizi sağlamaktadır.

Değer, olumlu olarak kabul edilen kişisel ve sosyal tercihler (Halstead, 1996), istenilen ve beklenilen davranış biçimleri (Aydın, 2011), hayata bakış açımızı etkileyen, kararlarımızı ve yaşamımızı şekillendiren ölçütler (Turan \& Aktan, 2008; Emiroğlu, 2011; Erikli, 2016; Çağlayan, 2018). insan hayatında önemli olan ve herkeste farklı derecelerde yer alan motivasyon araçları (Bardi \& Schwartz, 2003), insan ilişkilerine yön veren, seçimlerimizi belirleyen ve davranışlarımıza rehberlik eden standartlar olarak tanımlanabilir. Schwartz'a göre (2006) değerler inançtır, motivasyonel bir yapıya sahiptir, insanları istenilen davranış biçimlerine yönlendirir, norm ve tutum gibi kavramları içeren soyut hedeflerdir, davranışların seçilmesinde ve değerlendirilmesinde rehberlik eder ve belirli bir önem sırasına göre sıralanmıştır. Bir diğer tanımda değerler toplumda insanların bir arada yaşamasını sağlayan, çoğunluk tarafından kabul 
edilmiş, toplumların huzur ve refahını sağlayan, insanların yaşam kalitesini artıran kurallar bütünüdür şeklinde açıllanmaktadır (Aydın, 2011). Koç ve Akdoğan'a göre (2018) ise değerler kişinin bireysel ve toplum içindeki davranışlarını belirler. Bu davranışların belirlenme süreçlerinin başında ise aile gelmektedir.

Çocuğun ilk sosyalleştiği yer olarak kabul edilen aile, içinde yaşadığı toplumun değerlerini ve inançlarını çocuğa öğretmekle sorumludur. Anne babanın değer öncelikleri ve değer algıları çocuğun değerler sistemi üzerinde etkilidir (Whitbeck \& Gecas, 1988). Aile çocuğa davranış, tutum ve değer kazandıran, eğitimin ilk başladığı kurumdur. Değer kazanma sürecinde ailenin önemi çok büyüktür(Pala, 2011; Neslitürk, 2013; Yaşaroğlu,2016). Bireylerin davranışlar1 aile içi etkileşim ile oluşur, daha sonra toplumda gelenek, görenek, tutum ve davranışlar ile şekillenir. Bu nedenle aile çocuğun hem kişiliği hem sosyal ilişkileri üzerinde etkilidir (Aslan, 2011). Ailelerin çocukla sağliklı bir iletişim kurması, yoğun etkileşim içinde olması, çocuk herhangi bir ahlaki kuralı çiğnediğinde ailenin verdiği tepki, ahlaki kurallarla ilgili çocuğa açıklamalarda bulunması ve çocuktan ahlaki değerler kapsamında beklentilerini ifade etmelerinin sağlanması değer öğrenme sürecinin kolaylaştırır (Oladipo, 2009). Anne ve baba çocuğun kişiliğinin oluşmasında ve davranışlarının şekillenmesinde en önemli modellerdir (Kişi, 2009). Değişen yaşam şartları, teknolojinin gelişmesi, sosyal medyanın ve internet kullanımının artması anne babaların değerler noktasında sorumluluğunu artırmaktadır.

Birey üzerinde büyük etkisi olan değerlerin kazanımı tesadüflere bırakılmayacak kadar önemlidir. Burada eğitimin önemi ortaya çıkmaktadır. Değerlerin öğretilmesinin ve yaşatılmasının en önemli yollarından birisi eğitimdir. Değerler eğitimi, bireyin kendi özelliklerinin farkına varmasını, duygu, düşünce, davranış ve tutumları ile uyum içinde olmasını, neyin doğru neyin yanlış olduğuna dair yargıya varmasını ve davranışlarını buna göre şekillendirmesini sağlar (Akbaş, 2008). Değerler eğitimi bireylerde sevgi, saygı, sorumluluk, inanç, adalet gibi birçok değeri kazandırmanın yanında toplumda giderek artan ahlaki sorunlara çözüm bularak hem bireylerin hem toplumun daha güvenilir ve daha rahat yaşamasına imkân sağlamaktadır (Altan, 2011). Toplumların gelişimi, düzeni, yaşam kalitesi ve geleceğinde değerler eğitiminin rolü büyüktür (Neslitürk, 2013). Değerler eğitiminin amacı evrensel ahlaki değerlere sahip iyi karakterli bireyler yetiştirmek (Sağlam, 2016) ve bireyin kendisine ve topluma faydalı olacağı temel değerleri kazandırmaktır (Çağlayan, 2018).

Okul çocuklara değer kazandırma konusunda önemli ve etkili kurumlardan biridir(Aydın, 2011; Yaşaroğlu, 2016; Çetinkaya \&Yılmaz, 2017; Koç \& Akdo- 
ğan, 2017). Aile ile başlayan eğitim süreci toplum ve okul ile devam eder. Çocukların davranışları pekiştirilerek kalıcı hale getirilmeye çalışılır (Kara, 2017). Okulların temel görevlerinden biri programda açık veya örtük biçimde yer alan değerleri çocuklara kazandırarak onların ahlaki yönden gelişimlerini sağlamak ve kişiliklerini olumlu yönde etkilemektir (Akbaş, 2008). Çocuk okulda bilişsel alanla ilgili öğrenmelerle birlikte saygı, sevgi, hoşgörü, yardımseverlik, duyarl11ık, sorumluluk gibi toplumsal değerleri de öğrenme ve davranışa dönüştürme olanağı bulur. Bu nedenle okul ortamının sadece bilgi öğrenme değil aynı zamanda çocuklara değer kazandırma amacı kapsamında düzenlenmesi gerekmektedir (Çengelci ve ark., 2013).

Değerler eğitiminde öğretmenin önemli sorumluluğu vardır (Aktepe \& Yalçınkaya, 2016). Değerlerin öğretilmesinde öğretmenin kullandığı yöntem ve teknikler çok önemlidir (Kurtdede-Fidan, 2009). Okul programları değerler eğitimi konusunda ne kadar iyi düzenlenmiş olursa olsun öğretmen gereken önemi vermez ve dikkat etmezlerse değer öğretiminde istenilen hedeflere ulaşmak zordur (Katılmış, 2017). Öğretmen bilerek veya farkında olmadan sınıf ve okul içindeki tutum ve davranışlarıyla çocuklara değerleri aktarır. Öğretmen sınıf içinde gerçekleştireceği tartışma, diyalog gibi etkinliklerle öğrencileri değerler hakkında bilgilendirir ve dikkatlerini değerler üzerine çekerek düşünmelerini sağlar. Sınıf içinde sevgi, güven ve işbirliğine dayalı bir atmosfer oluşturarak değer gelişimine katkıda bulunur (Lakshmi \& Paul, 2018). Bu nedenle değer eğitiminde öğretmen hem değerler eğitimine ilişkin yeterli bilgi ve beceriye sahip olmalı hem de iyi bir model olmalıdır (Aktepe \& Yalçınkaya, 2016). Öğretmenin kendisine güvenmesi ve gerekli yeterliliğe sahip olması değerler eğitiminde ikna edici ve belirleyici rol oynar (Lovat, 2005). Öğretmenin çocukların ahlaki gelişimine en önemli katkısı iyi bir rol model olmaktır (Sanger \& Osguthorpe, 2013). Bu bilgiler doğrultusunda değer edinim sürecinde aile ve okulun ne kadar önemli olduğu şüphe götürmez bir gerçektir. Bireylerin değerleri içselleştirebilmeleri ve yaşantılarının bir parçası haline getirebilmeleri için bu iki önemli kurumunda eş güdüm halinde çalışmaları oldukça önemlidir. Eğitim süreci sadece öğrenci ve öğretmen ilişkisi üzerine inşa edilemez. Anne babalarında bu sürece katılmaları tartışılmaz bir gerçektir.

Anne babaların eğitim sürecine katılması hem olumlu davranış kazanımında hem de derslerin başarısının yükselmesinde etkilidir. Ebeveynler çocukların okul gelişimlerini takip etme, yeteneklerini keşfetme ve destekleme, okulun amaçlarını anlama ve buna göre hareket etme imkânı bulurlar. Aynı zamanda 
öğretmenlerde ailelerin çocuğun eğitim sürecine karşı bakış açısını ve amaçlarını anlar ve bu durumları göz önüne alarak ailelere destek olurlar (Powell ve ark., 2010). Öğretmenler çoğu zaman çocuğun tecrübesini, bilgisini, yeteneğini, olumlu tutumlarını ve ahlaki standartlarını öğrenme sürecinde kalıcılığı sağlamak ve bu özellikleri geliştirmek için ailenin aktif katılımına ihtiyaç duyarlar. Okul-aile işbirliğinin amacı çocukta görülen inatçılık, bencillik, tembellik, yalan söyleme ve uyumsuz davranışlar gösterme gibi olumsuz karakter özelliklerini en aza indirmek veya bu tür davranışları yok ederek yerine olumlu karakter özellikleri geliştirmektir (Clipa \& Iorga, 2012). Ailelerinin aktif olarak eğitim sürecine katıldığı çocukların akademik olarak daha başarılı oldukları ve davranış problemlerinin azaldığı görülmüştür. Karakter ve değer eğitiminde sosyal ve duygusal becerilerde geliştiği için çocuklara daha fazla fayda sağlar. Eğer okullar öğretim programlarına karakter eğitimini alır ve ailelerinde bu sürece katılımını sağlarlarsa bu durum çocuğun akademik olarak daha başarılı olacağı anlamına gelir (Hood, 2011). Değerler eğitiminde okul aile işbirliği davranışın kalıcı hale gelmesinde önemlidir. Ailede öğretilen değerler okulda desteklenirse kazandırılmak istenen değer daha kısa sürede öğretilir. Aynı şekilde okulda kazandırılmaya çalışılan değerler aile tarafından desteklenirse kısa sürede başarı elde edilir (Çağlayan, 2018).

Alanyazın incelendiğinde Türkiye'de değer eğitim sürecinde okul ve veli işbirliği üzerine yapılan çalışmalar okullarda değer eğitimi konusunda öğrenci ve öğretmen görüşlerini belirlemek (Çengelci ve ark., 2013), okullarda öğrencilere kazandırılması gereken değerlere ilişkin velilerin okuldan beklentilerini belirlemek (Selvitopu ve ark., 2015), okullarda öncelikli olarak verilmesi gereken değerlere ilişkin veli görüşlerini belirlemek (Yaka ve ark., 2014), okulda kazandırılması gereken değerlere ilişkin öğretmen, öğrenci ve veli görüşlerini belirlemek (Turan \& Aktan, 2008; Aslan, 2011; Aktepe \& Yalçınkaya, 2016). değer eğitimi kapsamında öğretmen, öğrenci ve velilerin birbirlerinden karşılık11 beklentilerini ortaya çıkarmak (Çelikkaya \& Yılmaz, 2017), değerler eğitimine yönelik veli ve öğretmen tutumlarını belirlemek (Çağlayan, 2018), öğretim programlarında yer alan değerlerin önemine ilişkin veli ve öğretmen görüşlerini belirleyerek benzerlik ve farklılıkları ortaya çıarmak (Acun ve ark., 2013), çocuklara değer aktarımın önemi ve bu süreçte okul ve ailenin rolü (Koç \& Akdoğan, 2018) üzerine olmuştur. Yapılan çalışmalarda değerler eğitiminde okul aile işbirliğinin önemi vurgulanmıştır. Çocuklar ilk olarak değerleri evde kazanır ve anne babalar ilk öğretmenleridir. Ebeveynlerin uygun rol model olması ve değerlerin aile ortamında yaşatılması değer kazanımında önemlidir. Evde baş- 
layan değerler eğitimi okulda devam eder. Değerlerin pekiştirilmesi ve kalıcı hale gelmesi için okul ve aile arasındaki işbirliği kilit rol oynar. Ailenin desteği olmadan okulda yapılanlar sadece öğretmenlerin çabasıyla sınırlı kalır. Bu nedenle aile ve okulun değer eğitiminde tutarlı olması ve işbirliği içinde çalışması gerekir (Yaşaroğlu, 2016). Değerler eğitiminde başarı için öğretmen ve ailelerin işbirliği içinde olması ve iyi birer rol model olmaları, aileye değerler eğitimi konusunda eğitimler verilmesi, değerler eğitiminin öğretim programlarında yer alması gerekmektedir (Çelikkaya ve ark., 2014). Velilere göre günümüzde öğrenciler teknoloji ve medyayla fazla vakit geçirmekte ve bu durum onların değer yargılarını olumsuz etkileyerek topluma yabancılaşmalarına sebep olmaktadır (Selvitopu ve ark., 2015). Çelikkaya ve Yılmaz (2017) tarafından değerler eğitiminde öğretmen, öğrenci ve velilerin karşılıklı beklentilerine ilişkin çalışmada en çok dürüstlük, hoşgörü, saygı, sevgi, vatanseverlik ve yardımseverlik değerlerinin öğretilmesi gerektiği vurgulanmış, öğretmenler sayg1 değerini veliler ise sorumluluk değerini öğretmekte sıkıntı yaşadıklarını belirtmişlerdir. Ancak çalışmaya katılan çoğu veliye göre okul, değer kazandırma noktasında beklentileri karşılayamamaktadır. Bunun nedeni akademik başarının ön planda olması, öğrenci davranışlarından ziyade bilgiye önem verilmesi gösterilmektedir.

Değerler eğitimi üzerinde durulması gereken en önemli konulardan biridir. Değerlerin kazanılması ve yaşatılması hem bireylerin hem toplumun geleceği açısından önemlidir. Değerler eğitimi ailede başlar okulda devam eder. Bu nedenle değerlerin öğrenilmesi ve yaşatılması için okul ve aile arasında işbirliği sağlanmas1 gereklidir.

Bu çalışma öğrencilerin değer edinim sürecinde veli ve öğretmen işbirliği sürecini, velilerin ve öğretmenlerin öncelik verdiği değerleri ve kazandırmakta zorluk çektikleri değerleri, veli ve öğretmenlerin birbirinden karşılıklı beklentilerini, değer kazandırma sürecinde hem velilerin hem öğretmenlerin değer eğitiminde kullandıkları yöntemleri ifade ettiği için diğer çalışmalardan ayrılmaktadır.

$\mathrm{Bu}$ araştırmanın amacı değer öğretimi sürecinde okul- aile işbirliğine ilişkin öğretmen ve veli görüşlerini belirlemektir. Bu amaca ulaşmak için aşağıdaki sorulara cevaplar aranmıştır:

- Değerler eğitimine yönelik öğretmen ve veli algıları nasıldır?

- Öğretmenlerin ve velilerin öncelik verdikleri değerler nelerdir?

- Çocukların kazanmalarında zorluk çektiklerini düşündükleri değerler hangileridir? 
- Değerler eğitimi kapsamında öğretmen ve velilerin birbirlerinden beklentileri nelerdir?

- Velilerin ve öğretmenlerin, değerleri öğretirken en çok kullandıkları yaklaşım, strateji veya yöntemler nelerdir?

\section{Yöntem}

$\mathrm{Bu}$ araştırmada değerler eğitiminde okul ve aile işbirliğinin önemi hakkında derinlemesine bilgi etmek için nitel araştırma deseni benimsenmiştir. Nitel araştırmada olay ve olgular kendi doğal ortamları içinde ayrıntılı bir şekilde incelenir (Yıldırım \& Şimşek, 2011). Nitel araştırma kişi veya grupla ilgili araştırılması gereken karmaşık bir problem hakkında varsayımla başlar. Nitel araştırma zaman alır, derinlemesine analiz ve betimleme gerektirir (Creswell, 2014).

\section{Çalışma Grubu}

$\mathrm{Bu}$ araştırma da katılımcılar kolay ulaşılabilir durum örnekleme yöntemi ile belirlenmiştir. Kolay ulaşılabilir durum örneklemesi araştırmaya hız ve pratiklik kazandırır. Araştırmacı erişilmesi kolay ve kendine yakın olan dir durumu seçer (Patton, 2001). Kolay ulaşıabilir durum örneklemesi ekonomiktir. Araştırmacılar için tanıdık bir örneklem üzerinde çalışmak daha elverişli ve kullanışlıdır (Yıldırım \& Şimşek, 2011). Çalışma grubunu Kayseri il merkezinde bulunan bir devlet okulunda 5. sınıf derslerine giren 10 öğretmen (4 İngilizce öğretmeni, 2 Türkçe öğretmeni, 1 Rehberlik ve Psikolojik Danışma Öğretmeni, 1 Din Kültürü ve Ahlak Bilgisi öğretmeni, 1 Fen ve Teknoloji Öğretmeni, 1 Sosyal Bilgiler Öğretmeni) ve 5. Sınıfta öğrencisi bulunan 10 veli oluşturmaktadır. Araştırmaya yaşları 34-45 arasında değişen beş bayan beş erkek öğretmen katılmıştıur. Araşırmaya katılan velilerden ise yedisi bayan dördü erkektir ve yaşları 30-45 arasında değişmektedir.

Tablo 1: Çalışma Grubuna Ait Demografik Bilgiler

\begin{tabular}{cccccc}
\hline \multicolumn{3}{c}{ Öğretmen Bilgileri } & & \multicolumn{3}{c}{ Veli Bilgileri } \\
\hline Bayan & Erkek & Toplam & Bayan & Erkek & Toplam \\
\hline 5 & 5 & 10 & 7 & 3 & 10 \\
\hline
\end{tabular}

\section{Etik Kurul Onayı}

$\mathrm{Bu}$ araştırmada etik sorun oluşturabilecek sorular/maddeler, süreçler ya da unsurlar bulunmadığına dair Erciyes Üniversitesi Sosyal ve Beşerî Bilimleri Etik 
Kurulundan 23.02.2021 tarih, 65 başvuru numaralı "Etik Kurulu Onay Belgesi”" alınmıştır.

\section{Verilerin toplanması}

Bu çalışmada veri toplama aracı olarak yarı yapılandırılmış görüşme tekniği kullanılmıştır. Yarı yapılandırılmış görüşme formunda şu sorulara cevap aranmıştır;

\section{Öğretmen görüşme soruları}

1. Değer nedir? Değeri nasıl tanımlarsınız?

2. Değerlerin nasıl kazandırılabileceğini düşünüyorsunuz.

3. Öğrencileriniz okula başladıklarında öncelikli olarak hangi değerlere sahip olmalarını beklersiniz? Neden?

4. Öğrencilere öncelikli olarak hangi değerler kazandırılmalıdır? Niçin?

5. Değerleri kazandırmaya çalışırken hangi yollara (yaklaşım, strateji ve yöntem) başvuruyorsunuz? Neden?

6. Kazandırmakta zorluk çektiğiniz değerler hangileridir? Neden?

7. Siz öğrenci olsanız öğretmeninizin size hangi değerleri aktarmasını isterdiniz? Neden?

8. Velilerden, hangi değerleri çocuklarına kazandırmalarını isterdiniz? Neden?

\section{Veli görüşme soruları}

1. Değer nedir? Değeri nasıl tanımlarsınız?

2. Size göre ailede çocuklara öncelikli olarak hangi değerler kazandırılmalıdir? Niçin?

3. Değerleri kazandırmaya çalışırken hangi yollara başvuruyorsunuz? Açıklar misiniz?

4. Hangi değerleri kazandırmak size göre zordur? Niçin?

5. (Çocuğunuza kazandırmaya çalıştığınız değerlerden hangilerinde zorland1ğınızı düşünüyorsunuz? Neden?)

6. Öğretmenlerden hangi değerleri çocuğunuza kazandırmalarını istersiniz? Neden? 
7. Hangi ders ya da derslerin değer kazandırmada etkili olduğunu düşünüyorsunuz? Neden?

Yar1 yapılandırılmış görüşme tekniği; araştırmaya katılanlardan derinlemesine veriler toplanabilmesine imkân verir, araştırmacıya görüşmeye katılanların söylediklerine göre ek sorular sorabilme imkânı sağlar ve bu teknikteki görüşme soruları esnektir (Merriam, 2013). Görüşme sırasında kullanılan form ilgili alan uzmanlarının görüşleri (Eğitim bilimlerinden 1, Karakter ve Değerler Eğitimi Yüksek lisans programında derse giren 3 öğretim üyesi) alınarak hazırlanmış, gerekli düzenlemeler yapılarak son hali verilmiştir. Görüşmeler öğretmenler ve velilerin müsait oldukları zamanlar gözetilerek gönüllülük esasına göre yapılmıştır. Toplam 10 öğretmen ve 10 veli ile tek tek görüşülmüş ve her biri görüşme yaklaşık 25 dakika sürmüştür. Görüşmelerin ses kaydı alınmış, daha sonra her bir görüşmenin ses kaydı çözümlenmiş, elde edilen kodlar ve temalar aşağıdaki tablolarda sunulmuştur.

\section{Veri Analizi}

Araştıra kapsamında yapılan görüşmelerde ses kayıt cihazı kullanılmıştır. Ses kayıt cihazı tarafından kaydedilen görüşmeler ses dosyası olarak bilgisayar ortamına aktarılıış ve deşifreler yapılmıştır. Word formatına aktarılan ses kayıtları eksik ve yanlış olmaması için yeniden dinlenerek kontroller yapılmıştır. Elde edilen veriler içerik analizi yöntemiyle incelenmiş, her soru başlığ altında verilen cevaplara göre kodlar çıkarılmıştır. Verilerin analizinde güvenirliğin sağlanabilmesi için görüşme formundan elde edilen veriler, araştırmacı ve Temel Eğitim Bölümünde görevli bir öğretim üyesi tarafından ayrı ayrı kodlanmıştır. Kodlama sonuçlarında aynı kodlamanın yapıldığı durumlar görüş birliği ve farklı kodlamanın yapıldığg durumlar görüş farklılığı olarak belirlenmiştir. Hesaplamalar sonucunda; kodlamalar arasındaki ortalama güvenirlik oranı $\% 92$ olarak bulunmuştur. Miles ve Huberman'a (1994) göre güvenirlik hesaplamasının \%70'in üzerinde çıkması araştırmanın güvenilir olarak kabul edilmesinde yeterlidir.

\section{Bulgular}

Bu bölümde öğretmen ve ailelerin değer öğretimi sürecinde okul- aile işbirliğine ilişkin görüşleri bağlamında; değerler eğitimine yönelik öğretmen ve veli alg1ları, öğretmenlerin ve velilerin öncelik verdikleri değerler, çocukların kazanmalarında zorluk çektiklerini düşündükleri değerler, değerler eğitimi kapsamında 
öğretmen ve velilerin birbirlerinden beklentileri ve velilerin ve öğretmenlerin, değerleri öğretirken en çok kullandıkları yaklaşım, strateji veya yöntemler neler olduğuna ilişkin görüşlerine yer verilmiştir. Yapılan görüşmelerde yer alan bütün yorumları eklemek mümkün olmadığı için her bulgu başlığı altına yapılan görüşmelerden elde edilen en dikkat çekici ve etkileyici yorumlar eklenmiştir. Ayrıca aynı frekansa sahip değerlerden ise biri seçilerek örnek verilmiştir.

\section{Değerler Eğitimine Yönelik Öğretmen ve Veli Algıları}

Araştırmaya katılan öğretmen ve velilerin değerler eğitimine yönelik bilişsel yapılarını gösteren kelimeler ve frekans değerleri Tablo 2'de verilmiştir.

\begin{tabular}{|c|c|c|c|c|}
\hline \multirow[t]{2}{*}{ Kategoriler } & \multicolumn{2}{|l|}{ Öğretmenler } & \multicolumn{2}{|l|}{ Veliler } \\
\hline & $\begin{array}{l}\text { Katılımcıla- } \\
\text { rın Frekansı }\end{array}$ & $\begin{array}{c}\text { Değer } \\
\text { tanımı algı } \\
\text { yüzdesi }\end{array}$ & $\begin{array}{c}\text { Katılımcıların } \\
\text { Frekansı }\end{array}$ & $\begin{array}{l}\text { Değer tanımı } \\
\text { algı yüzdesi }\end{array}$ \\
\hline Varoluş & 1 & 10 & & \\
\hline Olumlu Özelliklerin Toplamı & 1 & 10 & 1 & 10 \\
\hline Ahlaki Ölçütler & 1 & 10 & 2 & 20 \\
\hline $\begin{array}{l}\text { Topluma tabi olmak için asgari } \\
\text { kurallar }\end{array}$ & 1 & 10 & & \\
\hline Kıymetli ve değerli şeyler & 1 & 10 & 2 & 20 \\
\hline Etik kurallar ve davranışlar & 1 & 10 & & \\
\hline İnsani vasıflar & 1 & 10 & 1 & 10 \\
\hline Faydalı olunan konular & 1 & 10 & & \\
\hline $\begin{array}{l}\text { Duygu ve düşüncelin hayata } \\
\text { aktarılmas1 }\end{array}$ & 1 & 10 & & \\
\hline Ortak davranış biçimleri & 1 & 10 & & \\
\hline Yargılar & & & 1 & 10 \\
\hline Hisler & & & 1 & 10 \\
\hline Dürüstlük & & & 1 & 10 \\
\hline Sevgi ve sayg1 & & & 1 & 10 \\
\hline
\end{tabular}

Araştırmaya katılan öğretmen ve velilerle yapılan görüşmeler sonucunda öğretmenler değer tanımlarını farklı şekillerde ifade etmişlerdir. Tablo 2' de görüldüğü üzere öğretmenlerin ifadelerinden değer tanım kodları varoluş, olumlu özellikler toplamı, ahlaki ölçütler, topluma tabi olmak için asgari kurallar, kıymetli ve değerli şeyler, etik kurallar ve davranışlar, insani vasıflar, faydalı olunan konular, duygu ve düşüncelerin hayata aktarılması, ortak davranış biçimleri şeklindedir. Görüşme yapılan her bir öğretmen ifadesinden elde edilen kodların (f:1 \%10) olarak ortaya çıkmaktadır. Değer tanımı ile ilgili öğretmen görüşleri aşağıda verilmiştir; 
Ö-5: "Değer insanin fitratında olan yaradılışından gelen ve yaratılışının gereği de onun yok olduğu ana kadar onu her yönüyle klymetlendiren değerli şeyler olarak tanımlayabilirim".

Ö-10: "Değer bir milletin sosyal devamlılı̆̆ını sağlayan herkes tarafindan kabul görmüş ve herkes tarafindan ortak olarak belirlenen davranış biçimidir".

Araştırmaya katılan veliler ile yapılan görüşmeler sonucunda değerleri nasıl algıladıkları ile ilgili görüşmelerden elde edilen kodlarda ahlaki ölçütler (f:2 \%20), kıymetli ve değerli şeyler (f:2 \%20), olumlu özelliklerin toplamı, insani vasıflar, yargılar, hisler, dürüstlük, sevgi ve saygı şeklindedir. Değer tanımı ile ilgili veli görüşleri aşağıda verilmiştir;

V-1: "Değer bir grubun bir topluluğun önem verdiği, bir topluluğun devaminı sağlaması için önemsediği, üstün kıldı̆̆ı klymetlerdir."

V-8: “Insanı insan yapan en önemli özelliklerden birisidir. Değerler olmadığ sürece ne insan ne toplum yaşayamaz, huzurlu mutlu yaşayamaz ki onun için bu değerler gereklidir, önemlidir."

Öğretmen ve velilerin ortak değer tanım kodları ise olumlu özelliklerin toplamı, ahlaki ölçütler, kıymetli ve değerli şeyler ve insani vasıflar şeklindedir.

\section{Öğretmenlerin ve Velilerin Öncelik Verdikleri Değerler}

Araştırmaya katılan öğretmen ve velilerin öncelik verdikleri değerlere yönelik bilişsel yapılarını gösteren kelimeler ve frekans değerleri Tablo 3 'te verilmiştir.

Tablo 3: Öğretmenlerin ve Velilerin Öncelik Verdikleri Değerleri

\begin{tabular}{lcccc}
\hline Kategoriler & \multicolumn{2}{c}{ Öğretmenler } & \multicolumn{2}{c}{ Veliler } \\
\hline & $\begin{array}{c}\text { Katılımcıla- } \\
\text { rın Frekansı }\end{array}$ & $\begin{array}{c}\text { Öncelik Verilen } \\
\text { Değerler Yüzdesi }\end{array}$ & $\begin{array}{c}\text { Katılımcıların } \\
\text { Frekansı }\end{array}$ & $\begin{array}{c}\text { Öncelik Verilen } \\
\text { Değerler Yüzdesi }\end{array}$ \\
\hline Saygı & 7 & 15 & 6 & 15 \\
\hline Sevgi & 6 & 13 & 7 & 18 \\
\hline Adil olma & 4 & 8 & 1 & 3 \\
\hline Dürüstlük & 9 & 19 & 4 & 3 \\
\hline Paylaşıma & 2 & 4 & 1 & 3 \\
\hline Yardımse- & 3 & 6 & 1 & 3 \\
verlik & 1 & 2 & 3 & 3 \\
\hline Merhamet & 4 & 8 & 1 & 3 \\
\hline Hoşgörü & 2 & 4 & & 3 \\
\hline Özsaygı & 2 & 4 & 1 & 3 \\
\hline Güven & 2 & 4 & & \\
\hline Sorumluluk & & & & \\
\hline
\end{tabular}




\begin{tabular}{lllll}
\hline Çalışkanlık & 1 & 2 & 1 & 3 \\
\hline Empati & 1 & 2 & 1 & 3 \\
\hline Vatanseverlik & 1 & 2 & 1 & 3 \\
\hline Demokrasi & 2 & 4 & & \\
\hline İşbirliği & 1 & 2 & & 21 \\
\hline Güzel Ahlak & & & 8 & 3 \\
\hline Temizlik & & & 1 & 1 \\
\hline Erdem & & & 1 & \\
\hline
\end{tabular}

Araştırmaya katılan öğretmenler öncelik verdikleri değerlere en çok dürüstlük (f: $9 \% 19$ ) ve ardından saygı (f: 7 \% 15) cevabını vermişlerdir. Öğretmenlerin öncelik verdikleri değerler ile ilgili dürüstlük ve saygı değerlerinin öğretilmesine ilişkin görüşleri şu şekildedir:

Ö-10: “Birincisi dürüstlük. Çünkü kişinin hayatında her döneminde gerekli olan çocukluktan yaşlılığa kadar bir süreç, yaşamdaki bu süreç içerisinde gerekli tüm değerleri içinde barındıran bir değer olduğunu düşünüyorum dürüstlüğün. Her aşamada akademik ĕgitimine devam etsin etmesin insanlar hangi mesleği yaparsa yapsın iyi karakterli insan olarak, karakterin başında da dürüstlüğ̈̈n geldiğini düşündüğ̈üm için öncelikle dürüstlük olmalı.",

Ö-2: “Neden saygı çünkü sosyal ortamda insanların birbirleri ile iletişime geçebilmek için önce saygıyı ögrenmeleri gerekir. İletişimin temel ilkeleri arasında saygl vardır. Çünkü birbirini dinleyebilme özelliğini önceden edinmeli ki iletişim sağllkl ilerleye bilsin.”

Öğretmenler en az öncelik verilen değerlerden biri olarak işbirliği (f: \%2) değerini söylemişlerdir. İşbirliği değeri için öğretmen görüşü şu şekildedir:

Ö-10: “İşbirliği olumlu olumsuz hayatın akışı içerisindeki karşılaşılan problemlere karşı sinerji oluşturmak adına olması gereken bir değerdir."

Veliler ise öncelik verdikleri değerlere en çok sevgi (f: $7 \% 18$ ) ve ardından sayg1 (f: 6 \%15) değerlerine öncelik verdiklerini söylemişlerdir. Veli görüşleri şu şekildedir:

V-1: "Aile içinde sevgi ve saygı değerleri verilirse çocukların toplumdaki de birbirlerine değer verme miktarlarl artacaktır. Birbirlerini daha çok seveceklerdir, birbirlerini daha çok sayacaklardır. En azından saygı duymayı öğreneceklerdir. Birbirinin fikrine saygl duyacaklardır. Bunların kazandırllması toplum içinde yararlı olacă̆ını düşünüyorum."

Velilerin en az öncelik verdikleri değerlerden biri ise empati (f:1 \%3) değeri olmuştur. 
V-5: “Empati önemlidir. Insanı karşısındaki insanların nasıl düşündüğünü kendine yapılsa nasıl hissedeceğini düşünmelerini sağlar bence”.

Tablo 3 'te yer alan değerler hemöğretmenlerle hem de velilerle yapılan görüşmeler sonucunda elde edilmiştir. Araştırma sonuçlarına göre öğretmen ve velilerin öncelikli olarak kazandırılması gereken değerlere en çok verdikleri ortak cevaplar dürüstlük, sevgi ve saygı değerleri olmuştur.

\section{Öğretmenlerin ve Velilerin Kazandırmakta Zorluk Çektikleri Değerler}

Araştırmaya katılan öğretmen ve velilerin kazandırmakta zorluk çektikleri değerlere yönelik bilişsel yapılarını gösteren kelimeler ve frekans değerleri Tablo 4 'te verilmiştir.

Tablo 4: Kazandırmakta Zorluk Çekilen Değerlere Ait Kodları

\begin{tabular}{|c|c|c|c|c|}
\hline \multirow[t]{2}{*}{ Kategoriler } & \multicolumn{2}{|c|}{ Öğretmenler } & \multicolumn{2}{|c|}{ Veliler } \\
\hline & $\begin{array}{c}\text { Katılımcıların } \\
\text { Frekansı }\end{array}$ & $\begin{array}{c}\text { Kazandırmakta } \\
\text { Zorluk Çekilen } \\
\text { Değerler Yüzdesi }\end{array}$ & $\begin{array}{c}\text { Katılımcıların } \\
\text { Frekansı }\end{array}$ & $\begin{array}{c}\text { Kazandırmakta } \\
\text { Zorluk Çekilen } \\
\text { Değerler Yüzdesi }\end{array}$ \\
\hline Dürüstlük & 6 & 19 & 3 & 17 \\
\hline Sayg1 & 6 & 19 & & \\
\hline Paylaşma & 6 & 19 & & \\
\hline Adil olma & 3 & 10 & & \\
\hline Yardımseverlik & 2 & 6 & & \\
\hline Vefa & 1 & 3 & & \\
\hline Sorumluluk & 2 & 6 & 2 & 11 \\
\hline Öz sayg1 & 2 & 6 & & \\
\hline Çalışkanlık & 1 & 3 & 1 & 6 \\
\hline Hoşgörü & 1 & 3 & 1 & 6 \\
\hline İşbirliği & 1 & 3 & & \\
\hline Güzel ahlak & & & 3 & 17 \\
\hline Empati & & & 2 & 11 \\
\hline Sabir & & & 2 & 11 \\
\hline Kültürel değerler & & & 2 & 11 \\
\hline Güven & & & 1 & 6 \\
\hline Diğerleri & 2 & & 2 & 11 \\
\hline
\end{tabular}

Araştırmaya katılan öğretmenler kazandırmakta zorluk çektikleri değerlere en çok dürüstlük (f: $6 \% 19$ ) ardından saygı (f: $6 \% 19$ ) ve paylaşma (f: $6 \% 19$ ) cevaplarını vermişlerdir. Öğretmen görüşleri şu şekildedir:

Ö-9: "Kazandırmak da zorluk çektiğim dürüstlük. Çocuklara şunu demekten nefret ediyorum doğruyu söylersen sana bir şey yapmayacağım. Çünkü çocuk 
yapamadı̆̆ bir şey olduğu anda yalana başvurarak bundan kurtulabileceğini düşünüyor. Oysaki ben aynı düşüncede değilim çünkü silsile halinde bugün beyaz yalanlar söyleyen bir çocuk iki gün sonra bunu büyütüyor aileyi kandırmaya başlıyor ögretmeni kandirmaya başllyor. Daha sonra da bu tabii ki davranış haline geliyor ve bunu herkese yapmaya başliyor".

Ö-8: "Örneğin ögrrencilerimizi kaldırıp bir söz hakkı verdiğimizde veya bir fikrini sorduğumuzda, güzel cevap verdiği zaman öğrencilerimizin çoğu "işte ben" diye bir kavram kullaniyor. İste ben, işte bu benim falan. Yani ben buradan da görüyorum ki aşırı bir şekilde benlik duygusu var hem öğrencilerimizde hem toplumda. Ve bu yüzden şunu düşünüyorum birçok sorun eğer çözülmüyorsa, inat ediliyorsa veya uzuyorsa bunun temel nedenlerinden birinin bencillik olduğunu düşünüyorum."

Öğretmenlerin kazandırmakta zorluk çektikleri değerlere en az verdikleri cevaplardan biri vefa (f: $1 \% 3$ ) değeridir.

Ö-5: "Çocuklarımız maalesef ki vefa duygusundan uzaklar. Kendilerine karşı yapılan iyiliklerin, hizmetlerin değerini kıymetini bilmeyecek kadar birçoğun da bu vefasizlık var".

Veliler kazandırmakta zorluk çektikleri değerlere en çok dürüstlük (f: $3 \% 17$ ) değeri cevabını vermişlerdir. Veli görüşü şu şekildedir:

V-7: "Dürüstlük olmazsa karşındakine güvende olmaz, onun eksik taraflarını yanlış tarafların yakalamaya çalı̧̧mak zor, tamamen güvenirsen verimli olur diye düşünüyorum. Aile iliş̧kilerinde de böyle, çocuğumuz sorun olduğu zaman bana bir şeyler anlatırken onun acaba doğru mu söylüyor yalan mı söylüyor diye arkasindan düşünmek istemiyorum. Onun her söylediğine ben güvenmek istiyorum ve onlar da benim her söylediğimi güvensinler isterim”.

Velilerin verdikleri cevaplara göre kazandırmakta zorluk çektikleri en az olan değerlerden biri güvendir (f: 1 \%6). Bu konuda veli görüşü şu şekildedir:

V-2: "Bence güven konusu biraz kazandırması zor. Çünkü beklemediğiniz en ufak bir davranışta ya da sizin aklinızdan geçmeyen en ufak bir hareketiniz de onların size karşıya güven duyguları değişebiliyor. Çok çabuk sarsılan bir durum”.

Görüşülen velilerden ikisi bu soruya şu şekilde cevap vermişlerdir:

V-3: "Bence dışarıdan etkilenebilecek değerleri kazandırırken zorlaniyorum. Ben evde ne kadar temiz ol saygılı da ol desem de bakiyor ki çocuk hani başkası çöp atıyorsa aman bende attyım diyebiliyor." 
V-1: “Bence hiçbir de zor değildir ama bunu aile yaşıyorsa. Ama yaşamıyorsa zaten o değerin kelime olarak kazandırllması mümkün değildir. Ĕger bir Bayramı geldiğinde anne elini öptürmüyorsa çocuk onun ne olduğunu bilmez. Hadi büyüklerimizin elini öpelim, bu büyüklere karşı bir saygıdır işte."

$\mathrm{Bu}$ cevaplara göre diğerleri sütunu oluşturulmuştur. Araştırma sonuçlarına göre öğretmen ve veliler kazandırmakta zorluk çektikleri değerlere ortak cevap olarak en çok dürüstlük değeri cevabını vermişlerdir.

\section{Değerler Eğitimi Kapsamında Öğretmen ve Velilerin Birbirlerin- den Beklentileri}

Araştırmaya katılan öğretmen ve velilerin değerler eğitimi kapsamında birbirlerinden beklentilerini gösteren kelimeler ve frekans değerleri Tablo 5 'te verilmiştir.

Tablo 5: Değerler Eğitimi Kapsamında Öğretmen ve Velilerin Birbirlerinden Beklentilerini

\begin{tabular}{|c|c|c|c|c|}
\hline Kategoriler & & ğretmenler & & eliler \\
\hline & $\begin{array}{c}\text { Katılımcıların } \\
\text { Frekansı }\end{array}$ & $\begin{array}{c}\text { Öğretmen ve Velilerin } \\
\text { Birbirlerinden Bekle- } \\
\text { dikleri Değerler Yüzdesi }\end{array}$ & $\begin{array}{c}\text { Katılımcıların } \\
\text { Frekansı }\end{array}$ & $\begin{array}{c}\text { Öğretmen ve } \\
\text { Velilerin Birbirle- } \\
\text { rinden Bekledikleri } \\
\text { Değerler Yüzdesi }\end{array}$ \\
\hline Sorumluluk & 3 & 9 & 2 & 7 \\
\hline Sevgi & 5 & 15 & 5 & 17 \\
\hline Sayg1 & 6 & 18 & 5 & 17 \\
\hline Dürüstlük & 6 & 18 & 3 & 10 \\
\hline $\begin{array}{l}\text { İnanç boyu- } \\
\text { tunda manevi } \\
\text { değerler }\end{array}$ & 1 & 3 & & \\
\hline Yardımseverlik & 3 & 9 & & \\
\hline Paylaşma & 2 & 6 & & \\
\hline Hoşgörü & 2 & 6 & 3 & 10 \\
\hline Adil olma & 3 & 9 & 2 & 7 \\
\hline Çalışkanlık & 1 & 3 & 2 & 7 \\
\hline İşbirliği & 1 & 3 & & \\
\hline Merhamet & & & 2 & 7 \\
\hline Empati & & & 1 & 3 \\
\hline Güven & & & 1 & 3 \\
\hline Güzel ahlak & & & 2 & 7 \\
\hline Vatanseverlik & & & 1 & 3 \\
\hline
\end{tabular}

Araştırmaya katılan öğretmenler velilerden çocuklarına en çok dürüstlük (f: $6 \% 18$ ) ve saygı (f: $6 \% 18$ ) değerlerini kazandırmalarını beklediklerini ifade etmişlerdir. Öğretmen görüşleri şu şekildedir:

Ö-2: “Veliler çocuğa dürüst olmayl, adil olmayı etrafindaki kişilere saygılı olmayı öğretmeliler. Tabii bunları sadece sosyalleşme adına değil kendine karşı 
da dürüst olacak kendine karşı da adil olacak kendine de saygl duyacak. Bu her anlamda, fiziksel anlamda da sosyal anlamda da ilişkiler anlamında da bir kere bunun olması lazım. Veli bunu çocuğa aktarmalı ki çocuk da bunun sosyal ortamda aşılayabilmeli ya da uygulayabilmeli diye düşünüyorum."

Ö-4: “Velilerden beklentimiz dürüstlük konusunda. Öğrenci çok rahat yalan söylüyor. Bu çok basit bir konuda da olabiliyor ya da daha farklı konularda da olabilir. En basitinden ödevini yapma konusunda çok rahat yalan söyleyebiliyor. Bazen çocuk kitabımı evde unuttum diyerek kitabını çıkarmaya bile tenezzül etmiyor. Arkadaşlarına saygısızlık konusunda, öğretmenini yeteri kadar saymaması konusunda problemler yaşıyoruz. Bunlar aileden geliyor ve bu eksiklikler bizi maalesef ĕgitim öğretim ortamını da sıkıntıya sokuyor."

Öğretmenler velilerden kazandırmalarını bekledikleri değerlere en az cevap olarak verilen değerlerden biri inanç boyutunda manevi değerlerdir. (f: $1 \% 3$ ). Öğretmen görüşü ise şu şekildedir:

Ö-7: “İnanç boyutunda dini eğitim verilmesi, hani bunun içerisinde yardımlaşmayl, paylaşmayl, sevgiyi sayabiliriz."

Veliler ise öğretmenlerden çocuklarına öğretmelerini bekledikleri değerlere en çok saygı (f: 5 \% 17) ve sevgi (f: 5 \% 17) cevaplarını vermişlerdir. Veli görüşleri şu şekildedir:

V-7: “Saygı kesin bir ögretmen ve ögrenci ilişkisinde olmall. Çocukların arkadaşlarına olan saygısı da çok önemlidir. Çünkü saygı duyuyorsa eğer kimsenin hakkına saldırmadan kendi haklarını da koruyup başkalarının haklarına da saygl gösteriyorsa bu çerçevede güzel bir hayat sürebilirler diye düşünüyorum."

V-2: “Insanlara sırf insan olduğu için sevgi ve saygı duymasını isterdim. Belki her insana sevgi duymayabilir ama her insana mutlaka saygll olmasinı isterdim. Çünkü aynı şekilde karşılık görecektir. Bir insana saygılı davrandığınız zaman inanın o insan da size karşı saygılı davranacaktır.”

Veliler öğretmenlerden kazandırmalarını istedikleri değerlere en az verdikleri cevaplardan biri güven değeridir (f: $1 \% 3$ ). Veli görüşü ise şu şekildedir:

V-9: “Ben en çok özgüven kazandırmalarını istiyorum çünkü bir şeyi yaparken çocuklarımız o işi bilinçli yapmalı veya ben bu işi yapamam falan dememeli yani öz güven vermeniz sahibi olmalarl gerekir."

Araştırma kapsamında görüşme yapılan öğretmen ve veliler değerler eğitimi kapsamında birbirlerinden en çok saygı değerini öğretmelerini beklemektedirler. 


\section{Velilerin ve Öğretmenlerin Değerleri Öğretirken En Çok Kullandık- ları Yaklaşım, Strateji veya Yöntemler}

Araştırmaya katılan velilerin ve öğretmenlerin değerleri öğretirken en çok kullandıkları yaklaşım, strateji veya yöntemleri gösteren kelimeler ve frekans değerleri Tablo 6'da verilmiştir.

Tablo 6: Velilerin ve Öğretmenlerin, Değerleri Öğretirken En Çok Kullandıkları Yaklaşım, Strateji veya Yöntemleri

\begin{tabular}{|c|c|c|c|c|}
\hline \multirow[t]{2}{*}{ Kategoriler } & \multicolumn{2}{|c|}{ Öğretmenler } & \multicolumn{2}{|c|}{ Veliler } \\
\hline & $\begin{array}{l}\text { Katılımcıla- } \\
\text { run Frekansı }\end{array}$ & $\begin{array}{c}\text { Değer Kazandır- } \\
\text { ma Yöntemleri } \\
\text { Yüzdesi }\end{array}$ & $\begin{array}{l}\text { Katılımcila- } \\
\text { rin Frekansı }\end{array}$ & $\begin{array}{c}\text { Değer Kazan- } \\
\text { dırma Yöntem- } \\
\text { leri Yüzdesi }\end{array}$ \\
\hline Model olma & 9 & 30 & 5 & 24 \\
\hline Taklit yöntemi & 1 & 3 & & \\
\hline $\begin{array}{l}\text { Kendimden ve } \\
\text { çevremden örnekler } \\
\text { vererek }\end{array}$ & 3 & 10 & 3 & 14 \\
\hline Empati kurma & 1 & 3 & & \\
\hline Kitaplar, Film & 5 & 17 & 1 & 5 \\
\hline $\begin{array}{l}\text { Yaparak yaşayarak } \\
\text { öğrenme }\end{array}$ & 2 & 7 & 2 & 10 \\
\hline Ödüllendirme & 2 & 7 & & \\
\hline Motive etme & 2 & 7 & & \\
\hline Aileyi eğitmek & 1 & 3 & & \\
\hline Okul ortamında & 1 & 3 & & \\
\hline $\begin{array}{l}\text { Kişisel gelişim } \\
\text { teknikleri }\end{array}$ & 1 & 3 & & \\
\hline Ögüt verme & 2 & 7 & 6 & 29 \\
\hline Uyar1 & & & 1 & 5 \\
\hline $\begin{array}{l}\text { Önemli şahsiyetle- } \\
\text { rin yaşamlarından } \\
\text { örnekler vererek }\end{array}$ & & & 1 & 5 \\
\hline Sevgi ile & & & 1 & 5 \\
\hline Hoşgörü ile & & & 1 & 5 \\
\hline
\end{tabular}

Araştırmaya katılan öğretmenlerin değer öğretiminde en çok kullandıkları yöntem model olmadır (f: 9 \%30). Öğretmen görüşü ise şu şekildedir:

Ö-5: " Okulda öğretmenler öğrencilerin en büyük rol modelidir. Bu rol modelde de ögretmene çok şey düşmektedir. Öğretmenin de bunları kazandırabilmesi için hani Mevlana Celâlettin Rumi'nin ifadesiyle “Ya olduğun gibi görün ya da göründüğ̈̈n gibi ol” ifadesi vardır. Öğretmenler öğrencilerine öncelikle kendileri davranışlarıyla örnek teşkil etmelidir. Yalandan, riyakârlıktan, haksızlıktan, 
adaletsizlikten onlar kaçınmalıdır. Zaten bir şey söylemesine bile gerek kalmaz. “Ayinesi iştir kişinin lafa bakılmaz” derler. Ayna bizim davranışlarımızdır. Davranışlarımızla güzel örnek olursak bu değerlerin de kazandırılması daha mümkün olacaktır."

Öğretmenlerin en az kullandıkları yöntemlerden biri ise aileyi eğitmektir (f:1 \%3). Öğretmen görüşü şu şekildedir:

Ö-1: “Ben değerlerin en çok ailede kazanıldı̆̆ını düşünüyorum. O yüzden öncelikli olarak aileyi ĕgitmek de onun o değerlere sahip olmasını să̆lamak da fayda vardır."

Veliler ise değer öğretiminde en çok öğüt verme (f:5 \%24) yöntemini kullanmaktadırlar. Bu konuda veli görüşü şu şekildedir:

V-9: "Ben her zaman çocuklarıma şunu söylerim saygl görmek istiyorsan saygllı olmak zorundasınız. Sonuçta karşındaki öğretmenleriniz olsun arkadaşlarınız olsun her zaman için saygılı olmalısınız."

Velilerin değer kazandırmada en az kullandıkları yöntemlerden biri ise uyarıdir (f:1 \%5). Veli görüşü şu şekildedir:

V-4: "Değerleri kazandırmaya çalışırken öncelikle yanlış yapıldı̆̆g zaman o konuda uyarma yaparım, yani şu şekilde yapılırsa daha doğru olur çünkü sana yapılmayan bir şeyi başkasına yapmam yanlıştır, başkasına bu şekilde zarar verebilirsin gibi anlatmaya çalışırım."

Araştırma sonuçlarına öğretmenlerin ve velilerin değer kazandırmada en çok kullandıkları ortak yöntem model olmadır.

\section{Öğretmenlere Göre Değerlerin Nasıl Kazandırılabileceği}

Araştırmaya katılan öğretmenlerin değerlerin nasıl kazandırılabileceğine dair görüşlerini gösteren kelimeler ve frekans değerleri Tablo 7'de verilmiştir.

\begin{tabular}{lcc}
\hline \multicolumn{2}{l}{ Tablo 7: Değerlerin Nasıl Kazandırılabileceğine Dair Ö̆gretmen Görüşleri } \\
\hline Kategoriler & \multicolumn{2}{c}{ Öğretmenler } \\
\hline \multicolumn{4}{l}{ Katılımcıların Frekansı } & Değerlerin nasıl kazandırılabileceği yüzdesi \\
\hline Aile & 7 & 18 \\
\hline Okul & 6 & 16 \\
\hline Çevre & 4 & 11 \\
\hline Toplum & 3 & 8 \\
\hline Örnek olmak & 3 & 8 \\
\hline Değerler eğitimi dersi & 2 & 5 \\
\hline
\end{tabular}




\begin{tabular}{lll}
\hline Anne & 1 & 3 \\
\hline $\begin{array}{l}\text { Önce kendine değer } \\
\text { vererek }\end{array}$ & 1 & 3 \\
\hline Arkadaşlar & 1 & 3 \\
\hline İletişim araçları & 1 & 3 \\
\hline Yaparak yaşayarak & 4 & 11 \\
\hline Öğretmenler & 1 & 3 \\
\hline Empati & 1 & 3 \\
\hline Taklit yoluyla & 1 & 3 \\
\hline Motive etmek & 1 & 3 \\
\hline $\begin{array}{l}\text { Önemli şahsiyetlerden } \\
\text { kişisel aktarımlar }\end{array}$ & 1 & 3 \\
\hline
\end{tabular}

Araştırma sonuçlarına göre öğretmenler değerlerin en çok ailede (f: $7 \% 18$ ) ve okulda (f: $6 \% 16$ ) kazandırılabileceğini düşünmektedir. Öğretmen görüşleri şu şekildedir:

Ö-5: "Bence ilk olarak aile gelir. Çünkü insan ailenin içerisinde doğar orda büyür orda gelişir dünyayı ilk olarak ailede tanır. Tabii bilerek y a da bilmeyerek ailenin sahip olduğu değerleri de kazanmaya başlar. O yüzden ailenin gerçek manada insan insan yapan diye tanımladı̆̆ımı o değerlere sahip olması çocuğun öncelikle o değerleri kazanmasındaki ilk adımdır."

Ö-9: "Bir kere ben her şeyin, eğitimin, terbiyenin ailede başladığı düşünüyorum. Değerlerinde yine aileden çocuklara geçtiğini düşünüyorum. Tamam, belki tek yargı aile olmayabilir ama ilk önce orada başlamalı. Başlamalı ki çocuk önce annede babada görmeli, sonra kendisi bunu yaşamal, sonra da okula geldiğinde yine ĕgitim ile beraber değer ölçülerimiz değer yargllarımız değer ifadelerimizi okulda da devam ettirilmeli."

Öğretmenlere göre değerleri en az kazanabileceği durumlardan birine önce kendine değer verme şeklinde cevap vermişlerdir (f:1\%3). Öğretmen görüşü şu şekildedir:

Ö-6:" Bir kere bence önce insan kendine değer verecek. Kendini seven insan başkalarını da sever ve saygı gösterir. Kendine değer veren insan başkalarına da değer verir. Kendine karşı dürüst kendine karşı işte adaletli yargllamadan hareket eden insan başkalarına da aynı şekilde davranır. Kendini seven başkasinı da sever. Kendini sevmeyen başkasinı sevmez."

\section{Öğrencilerin Okula Başladıklarında Sahip Olması Gereken Değerler}

Araştırmaya katılan öğretmenlerin, öğrencilerin okula başladıklarında sahip olması gereken değerlere dair görüşlerini gösteren kelimeler ve frekans değerleri Tablo 8'de verilmiştir. 


\begin{tabular}{lcc}
\hline Tablo 8: Öğrencilerin Okula Başladıklarında Sahip Olması Gereken Değerlere Ait Öğretmen Görüşleri \\
\hline Kategoriler & $\begin{array}{c}\text { Öğretmenler } \\
\text { Katılımcıların Frekansı }\end{array}$ & $\begin{array}{c}\text { Öğrencilerin Okula Başladıklarında } \\
\text { Sahip Olması Gereken Değerlerin Yüzdesi }\end{array}$ \\
\hline Saygı & 6 & 13 \\
\hline Sevgi & 3 & 7 \\
\hline Paylaşma & 1 & 2 \\
\hline Özsaygı & 4 & 9 \\
\hline Hoşgörü & 2 & 4 \\
\hline Sorumluluk & 2 & 4 \\
\hline Dürüstlük & 10 & 22 \\
\hline Adil olma & 5 & 11 \\
\hline Güven & 2 & 4 \\
\hline Çalıskanlık & 1 & 2 \\
\hline Empati & 2 & 4 \\
\hline Sabır & 1 & 2 \\
\hline Merhamet & 5 & 11 \\
\hline Yardımseverlik & 1 & 2 \\
\hline İyilik & 1 & 2 \\
\hline
\end{tabular}

Araştırmaya katılan öğretmenler öğrenciler okula başladıklarında öncelikle dürüstlük (f: $10 \% 22$ ) ve sayg1 (f:6 \%13) değerlerine sahip olmaları gerektiğini söylemişlerdir. Öğretmen görüşleri şu şekildedir:

Ö-8: “Okula başladıklarında bence kesinlikle sevgi, saygl, merhamet ve dürüstlük özellikle bu dördünü söyleyebilirim bana göre hayatta düzgün ve güzel bir şekilde yaşayabilmek için olmazsa olmaz değerlerdir diye düşünüyorum. Yani sevginin saygının merhametin ve dürüstlüğün birçok sorunu birçok şeyi halledebileceğini düşündüğüm için bu fikirdeyim."

Ö-2: “Tabi en başta dürüstlük çünkü öncelikle karşınızdaki kişinin duygularını dürüstçe ifade etmesi gerekir ki ne düşündüğ̈̈nü anlayabilelim ya da olaylara bakış açısına dürüstçe ifade etmeli ki gerçekten bir şey kazandırdık mı kazandlramadık mı bunu ögrenmemiz gerekiyor o yüzden doğruluk ve dürüstlük başta olmasi gereken değerdir."

Öğretmenler öğrencilerin okula başladıklarında sahip olması gereken değerlere en az verdikleri cevaplardan biri paylaşma (f: $1 \% 2$ ) değeridir.

Ö-1: “Artık bu çağa gelmiş olan bir öğrencinin mutlaka hani birtakım eşyalarını olabilir duyguları olabilir bunları arkadaşlarıla paylaşmayı öğrenmiş olmalı diye düşünüyorum. Biz en çok bu konuda sıkıntı yaşıyoruz. Karşımıza gelen ögrenciler de bunları eksik olarak görebiliyorum. " 


\section{Değer Kazandırmada Etkili Olan Dersler}

Araştırmaya katılan velilerin, değerleri kazandırmada etkili olan derslere dair görüşlerini gösteren kelimeler ve frekans değerleri Tablo 9' da verilmiştir.

\begin{tabular}{lcc}
\hline Tablo 9: Değer Kazandırmada Etkili Olan Derslere Ait Veli Görüşleri \\
\hline Kategoriler & Öğretmenler & \\
\hline & Katılımcıların Frekansı & $\begin{array}{c}\text { Değer Kazandırmada Etkili Olan } \\
\text { Dersler Yüzdesi }\end{array}$ \\
\hline Türkçe & 7 & 28 \\
\hline Sosyal bilgiler & 7 & 28 \\
\hline Din kültürü ve ahlak bilgisi & 7 & 28 \\
\hline Görsel sanatlar & 1 & 4 \\
\hline İngilizce & 1 & 4 \\
\hline Tüm dersler & 2 & 8 \\
\hline
\end{tabular}

Araştırmaya katılan veliler değer kazandırmada Türkçe (f: 7 \%28), Sosyal bilgiler (f: $7 \% 28$ ) ve Din Kültürü ve Ahlak Bilgisi (f: $7 \% 28$ ) derslerinin etkili olduğunu belirmişlerdir. Değer kazandırmada etkili olan dersler konusunda veli görüşleri şu şekildedir:

V-3: “Karşılıklı birbirlerine saygı duymaları, güvenilir olma, karşı tarafa güven vermeleri konusunda ya da işte ahlak konusunda çocuklar için önemli olduğunu düşünüyorum Din Kültürü ve Ahlak Bilgisi dersinin."

V-10: "Türkçe dersinin önemli olduğunu düşünüyorum. Okuduğu hikayelerden empati kurabilir, oradakileri örnek alabilir."

V-6: "Sosyal bilgiler dersinin milli değerlerimiz ve vatanseverlik konusunda etkili olduğunu düşünüyorum."

Araştırmaya katılan velilerden biri değer kazandırmada derslerden ziyade öğretmenin kişiliğinin ve yaptığı uygulamaların etkili olduğunu söylemiştir.

V-1: "Hepsi birbiriyle bütün hiçbir değeri işte sosyal bilgiler de verelim fen bilimlerinde verelim şurada verelim diye bir ayrım görmüyorum ben hepsinde verilebilir. Önemli olan adaletli, şeffaf ve hoşgörülü olacak yani hep sosyal dersleri üzerine bu konular yükleniyor ama bence bir sayısalcı da dürüstlükle başarıyı çarpıp çok yüksek bir sonuç ortaya koyabilir her dersin bence katkısı vardır, birbirinden ayrılmaz bir bütündür."

Ayrıca görüşme yapılan velilerden biri İngilizce dersinde öğretmenin yaptığ1 uygulamaların öğrencide adalet ve empati değerlerini geliştirdiğini belirtmiştir.

V-5: "Ingilizce dersinde her ögrrencinin sırayla başkanlık yapması adaletli olmayı ve empati değerini vurgulamaktadır. Mesela benim çocuğum hareketli ve 
konuşkan bir çocuk. Kendisine başkanlık sırası geldiğinde konuşan arkadaşlarını sürekli uyardı̆̆ını ve bu durumdan rahatsı olduğunu, diğer arkadaşları başkanlık yaparken onların nasıl hissettiğini anladı̆̆ını söyledi.'

\section{Öğretmenlerin Öğretmesi Gereken Değerler}

Araştırmaya katılan öğretmenlerin hangi değerlerin öğretilmesini gerektiğine dair görüşlerini gösteren kelimeler ve frekans değerleri Tablo 10’ da verilmiştir.

\begin{tabular}{lcc}
\hline \multicolumn{2}{l}{ Tablo 10: Öğretmenden Öğretmesi Beklenilen Değerler } & \multicolumn{2}{c}{ Öğretmenler } \\
\hline Kategoriler & $\begin{array}{c}\text { Katılımcıların } \\
\text { Frekansı }\end{array}$ & $\begin{array}{c}\text { Öğretmenden Öğretmesi Beklenilen Değerlerin } \\
\text { Yüzdesi }\end{array}$ \\
\hline Adil olma & 4 & 12 \\
\hline Sevgi & 5 & 15 \\
\hline Saygı & 5 & 15 \\
\hline Paylaşımc1lık & 2 & 6 \\
\hline Dürüstlük & 5 & 15 \\
\hline Hoşgörü & 1 & 3 \\
\hline Çalışkanlık & 2 & 6 \\
\hline Sorumluluk & 1 & 3 \\
\hline Yardımseverlik & 2 & 6 \\
\hline Güzel ahlak & 3 & 9 \\
\hline Merhamet & 2 & 6 \\
\hline Vatanseverlik & 1 & 3 \\
\hline İşirliği & 1 & 3 \\
\hline
\end{tabular}

Araştırmaya katılan öğretmenlerin görüşlerine göre bir öğretmen öğrencilerine en çok dürüstlük (f:5 \%15), sayg1 (f:5 \%15) ve sevgi (f:5 \%15) değerlerini öğretmelidir. Bu konuda öğretmen görüşü şu şekildedir:

Ö-5:" Ben öğretmenimden şunu beklerdim yapmadı̆̆ şeyi söylemesin ya da söylemediği şeyi yapmasın. Evet, doğru sözlü olsun, çünkü yani 30-40 kişilik sınıflarda bu kadar ögrenci oluyor her birine aynı gözle bakabilmeyi her birini aynı şekilde sevebilmeyi becerebilmesi lazım yani bu mümkün müdür bilmiyorum ama en azından bu gayreti göstermesi lazım. Bir de sevmesi lazım yani karşındaki kişiye onu sevdiğini belirtecek davranışları cümleleri ifade edebilmesi bunu gösterebilmesi gerekir."

Öğretmen görüşlerine göre öğretmenden öğrencilerine öğretmesi gereken değerlere en az verilen cevaplardan biri işbirliği değeridir (f:1 \%3). Öğretmen görüşü şu şekildedir:

Ö-10: "Daha çok iş birliğini isterdim. Çünkü işbirliği noktasında daha çok çözüm üretme ve problem çözme konusunda Iş̧birliği ve grup çalışması daha ön plana çıkacak bir davranışı olduğu için işbirliğini isterdim." 


\section{Tartışma ve Sonuç}

Araştırmaya katılan veliler ve öğretmenlerden elde ettiğimiz değer tanımlarının, alanyazında yer alan değer tanımları ile benzerlik gösterdiği anlaşılmaktadır. Değer tanımları olumlu özelliklerin toplamı (Aydın, 2011), ahlaki ölçütler (Turan \& Aktan, 2008; Emiroğlu, 2011; Erikli, 2016; Çağlayan, 2018), toplumsal yaşamda var olması gereken kurallar (Koç \& Akdoğan, 2018) olarak tanımlanmıştır. Değerler ile ilgili yapılan başka bir araştırmaya katılan öğretmenler değerleri toplumu bir arada tutan, kültürel özelliklerin gelecek nesillere aktarılmasını sağlayan kurallar olarak tanımlamışlardır (Dere \& Yavuzay, 2020). Sosyal bilgiler öğretmenleri değeri kıymet, insan, toplumsal kurallar maddi ve manevi ögeler olarak tanımlamışlardır (Çelikkaya \& Filoğlu, 2016). Öğretmenler değer kavramı için önem, kıymet, ölçüt, bedel, yarar gibi farklı tanımlarda bulunmuşlardır. Değerin hem bireyin toplumsal yaşama uyum sağlamasında hem de toplumun kurallarının devamlılığı açısından önemli olduğu vurgulanmıştır. (Balcı \& Yanpar, 2010).

Araştırma kapsamında öğrencilere kazandırılması gereken öncelikli değerlerle ilgili olarak öğretmenler dürüstlük, saygı ve sevgi şeklinde belirtirken veliler öncelikli olarak güzel ahlak, sevgi ve saygı olarak belirtmişlerdir. Araştırma sonucunda elde edilen öğretmenlerin görüşleri alanda yapılan faklı çalışma sonuçlarıyla (Çengelci ve ark., 2013, Uzun \& Köse 2017; Dere \& Yavuzay 2020). büyük bir oranda örtüşmektedir. Dere ve Yavuzay'ın çalışmalarında öğretmenlerin kazandırmak istediği öncelikli değerlerde ilk sırada vatanseverlik sonucu çıkmıştır. Bu araştırmanın sosyal bilgiler öğretmenleri ile yapılmış olması böyle bir sonucun çıkmasında büyük bir etken olduğu düşünülebilir. Aslan (2019) pedagojik formasyon alan öğretmen adaylarının değer önceliklerini incelediği çalışmasında benzer bulgulara ulaşmıştır. Adayların araç değerlerden en çok dürüstlük değerini tercih ettiklerini belirtmiştir. Çelikkaya ve Kürümlüoğlu'nun (2017) çalışmasında öğretmen ve velilerin 20 değer içinden ilk beşte sıraladıkları değerlerden ilk dördü (dürüstlük, sayg1, adil olma ve vatanseverlik) olarak belirlenmiştir. Bu sonuç yapılan araştırmanın sonuçlarıyla büyük oranda örtüşmektedir. Dinçer ve Gözel'in (2019) yllında yaptıkları araştırmada öğretmenlerin öncelikli değer sıralamasında ilk üç sırayı saygı, sorumluluk ve sevgi değeri aldığı görülmektedir. Okul öncesi öğretmenleri arasında yapılan araştırma sonuçlarına göre öğretmenler en çok saygı ve sevgi değerlerine öncelik verdiklerini belirtmiş̧lerdir (Uzun \& Köse, 2017). Araştırma sonuçlarına göre sosyal bilgiler öğretmenlerinin öncelik verdiği ilk üç değer dürüstlük, sevgi ve adalet 
olarak belirlenmiştir (Ünlü \& Kaşkaya, 2018). Tay ve Yıldırım (2009) '1n yapt1ğ1 çalışma sonuçlarına göre velilerin önem verdikleri değerleri sıraladıklarında sayg1 (80), dürüstlük (47), sevgi (41) değerleri ön plana çıkmaktadır. Dürüstlük değeri araştırmaya katılan hem veliler hem öğretmenler için öncelikle değerler arasındadır (Arpacı, 2014). Öğretmenler en çok saygı değerinin kazandırılmasını istediklerini belirmişlerdir. Saygı değerini özellikle aileye, çevreye, hak ve özgürlüklere sayg1 olarak ifade etmişlerdir (Çelikkaya \& Filoğlu, 2014). Öğretmenler en çok saygı değeri üzerinde durduklarını belirtmişlerdir (Yıldırım ve ark., 2017). Öğretmen adaylarının katıldığı araştırma sonuçlarına göre adil olma (84) ve saygı (60) değerleri tercih edilen ilk beş değer arasında yer almıştır (Kalın, 2017). Velilerin ise çocuklarında öncelikle adalet, dürüstlük ve vatanseverlik değerlerinin kazandırılması gerektiğine inandıkları göze çarpmaktadır. $\mathrm{Bu}$ sonuç araştırmanın bulgularıyla benzerlik göstermektedir. Sarıkaya (2019) 20 ebeveyn ile yapmış olduğu çalışmada öncelikle ebeveynlere genel bir soruyla yetiştirme değerleri konusunda neye önem verdikleri sorulmuştur. Bu soruya verilen cevaplardan katılımcıların çoğunun; ahlaki değerler, dini eğitim, sayg1 ve sevgi, dürüstlük değerlerine önem verdiği görülmüştür. Bu bulgu araştırmanın bulgularıyla örtüşmektedir. Araştırma sonuçlarına göre öğretmen ve velilerde saygı, sevgi ve dürüstlük değerleri ön plana çıkmaktadır. Bu değerleri ahlaki değerler olarak nitelendirebiliriz.

Araştırma sonucunda öğretmenlerden elde edilen görüşlere göre öğrencilere kazandırmakta zorluk çekilen değerler sırasıyla dürüstlük, saygı, paylaşma, adil olma, sorumluluk, yardımseverlik, özsaygı, vefa, çalışkanlık, hoşgörü ve işbirliği olurken veliler ise en çok dürüstlük ve güzel ahlak değerlerini kazandırmakta zorluk çektiklerini belirtmişlerdir. Yapılan araştırmalarda öğretmenlerin okul ortamında en çok kazandırmakta zorlandıkları değerin ise sorumluluk olduğu ifade edilmektedir (Aslan, 2007; Çengelci ve ark.,2013; Aktepe \& Yalçınkaya, 2016). Selvitopu, arkadaşlarının (2015) yaptığı çalışma sonucuna göre velilerin sorumluluk değerini kazandırmakta problem yaşadıkları belirlenmiştir. Alanyazında yapılan bu çalışmaların sonuçları araştırmadan elde edilen sonuçlarla benzerlik göstermektedir.

Çalışmadan elde edilen bulgulara göre veliler ve öğretmenler birbirlerinden en çok dürüstlük, saygı ve sevgi değerlerini öğretmelerini beklemektedirler. Selvitaşı, Bora ve Taş'ın (2015) yaptığı çalışmaya göre velilerin okuldan çocuklara öğretilmesini bekledikleri değerler arasında saygı değeri ilk akla geken değerler arasındadır. Yiğittir (2010) tarafından yapılan çalışmaya göre ise 
velilerin okulda en çok kazandırılmasını istedikleri değerler dürüstlük ve sayg1 değerleri olmuştur. Öğretmenlerin en çok bekledikleri değerler dürüstlük, sorumluluk, adil olma ve saygı değerleridir. Velilerin en çok beklenti içinde oldukları değerler dürüstlük, sorumluluk, sayg1 ve adil olma değerleridir (Acat \& Aslan, 2011). Öğretmenler ve veliler birbirlerinden en çok dürüstlük, hoşgörü, sayg1 ve sevgi değerlerinin öğretilmesini beklemektedirler (Çelikkaya \& Yılmaz, 2017). $\mathrm{Bu}$ araştırmaların bulguları çalışmamızın bulguları ile örtüşmektedir.

Araştırmada ulaşılan bir diğer sonuç öğretmenlerin çocuklara değer kazandırmada en çok model olma, yaşantılardan örnekler verme, kitaplar ve filmlerden yararlanma, velilerin ise en çok öğüt verme, model olma ve yaşantılardan örnekler verme yöntemini kullandıkları belirlenmiştir. Selvitaşı, Bora ve Taş 'ın (2015) yaptığı araştırmaya göre veliler değer kazandırırken en çok model olma ve öğüt verme yöntemlerini kullanmışlardır. Aktepe ve Yalçınkaya (2016) 'ya göre öğretim programları değerler eğitimine yönelik düzenlenmeli, örnek olaylar, önemli şahsiyetlerin hayatları, çeşitli kitaplar ve filmler etkin bir şekilde kullanılmalıdır. Öğretmenin rol model davranışlarının öğrenciye değer kazandırmada etkisi çok büyüktür (Ateş, 2013). Öğretmenler tarih dersinde değer öğretimi için en çok kullandıkları yöntemler model olma, kitap ve film analizlerinden yararlanmadır (Yiğittir \& Öcal, 2011). Değer öğretimi günümüzde farklı bir boyut kazanmıştır. Eskiden toplum içindeki yaşantılar yoluyla değerler aktarılabilirken günümüz koşullarında sadece yaşantılar yeterli olmamakta, değer öğretimi farklı yöntemlerle desteklenmelidir (Koç \& Akdoğan, 2018). Çocukta değer eğitimi ailede başlar, değer yargıları ailede oluşur. Değerler eğitimi ilk olarak ailede başlar ve ebeveynler ilk öğretmenleridir. Anne babanın evde rol model olması çok çocukta değer yargılarını oluşturmakta çok önemlidir. Okulda ise öğretmen değer eğitiminde önemli bir figürdür (Yaşaroğlu, 2016). Öğretmenler değerlerin öğretiminde en çok rol model olma, örnek olaylardan yararlanmayı tercih ederken veliler ise yine öğretmenler le aynı olarak rol model olmayı ögretmenlerden farklı olarak nasihat verme yöntemini tercih etmişlerdir (Çelikkaya \& Yılmaz, 2017). Model olma öğretmenlerin değer öğretiminde en çok kullandıkları yöntemlerden biridir (Kurtdede-Fidan, 2009). Değerler eğitiminde model olma ve öğüt verme öğretmenlerin en sık kullandığ1 öğretim yaklaşımlarıdır (Can, 2008). Araştırma kapsamında öğretmenlerin değer öğretiminde en çok model olma yöntemini kullandıkları, öğrencilere örnek olabilecek davranışlar sergilemeye çalıştıkları belirlenmiştir (Yaşar \& Çengelci, 2012). Öğretmenler değerler eğitimi kapsamında en çok iyi bir model olmaya çalıştıkları görülmüştür (Çelikkaya \& Filoğlu,2014). Değer eğitimi sürecinde 
öğrencilere doğru davranışları kazandırmak için öğretmenlerin iyi birer örnek rol model olmaları gerektiği belirtilmiştir (Yıldırım ve ark., 2017). Öğretmen algılarına göre etkili bir öğretmen davranışlarıyla model olmalı ve güzel bir ahlaka sahip olmalıdır (Şahin, 2011). Ebeveynlerin davranışları ve inançları çocuğun hayatının şekillenmesinde ve değer yargılarının oluşumunda etkilidir (Lazarides ve ark., 2015). Alanyazından elde edilen bulgular bizim çalışma sonuçlarımızı destekler niteliktedir.

Araştırmaya katılan öğretmenler değerlerin en çok ailede ve okulda kazandırılabileceğini belirtmişlerdir. Değerler eğitiminde ilk önce aile gelir, okul ise ailede öğrenilen değerleri pekiştirir veya yanlış öğrenmeleri düzeltmeye çalışır (Baydar, 2009). Aile çocuğun ilk değerleri kazandığı yerdir. Çocuk anne babanın davranışlarını gözlemleyerek temel davranışları öğrenirler. Yapılan araştırma sonucuna göre öğretmenler değer eğitimin de ailenin önemli rolü olduğunu, çocuğun değer kazanımında belirleyici en önemli etken olduğu görüşündedir (Akbaş, 2004). Araştırmaya katılan öğretmenlerin çoğu $(\% 88,5)$ okullarda değerler eğitimi verilmesinin önemli olduğunu ifade etmişlerdir. Okulda verilen değerler eğitiminin aile tarafından desteklenmesi ve pekiştirilmesi gerektiği böylelikle davranışların daha kalıcı olacağı görüşünü belirtmişlerdir (Gür ve ark., 2015). Araştırma sonuçlarından elde edilen verilere göre okul, aile ve çevre değerler eğitiminde oldukça etkilidir. Ayrıca okul, aile ve çevre işbirliği değerlerin kazandırılmasın önemlidir (Çengelci ve ark., 2013). Öğretmenler değer eğitimde ailenin önemli rolü olduğunu ayrıca ailenin sosyo-ekonomik şartları, eğitim düzeyi gibi faktörlerin bu süreci etkilediğini belirtmişlerdir (Berkant, Efendioğlu \& Sürmeli, 2014). Araştırmaya katılan öğretmenler hem ailenin hem okulun değerleri kazandırma sürecinde rol model olmaları gerektiği fikrini öne sürmüşlerdir (Ünlü \& Kaşkaya, 2018). Öğretmenler değerler eğitiminde en etkili faktörün aile, devamında ise çocuğun içinde bulunduğu ve şekillendiği çevre ve okul olarak ifade etmişlerdir (Çelikkaya \& Filoğlu, 2014). Değerlerin kazandırılması ve davranışların devamlılığı noktasında okul, aile ve çevre işbirliğine ihtiyaç vardır. Okullara değerler eğitimi konusunda büyük görev düşmektedir. Aile tarafından tam olarak verilmemiş veya yanlış kazandırılmış değerlerin doğru davranışlara dönüştürülmesi okul sayesinde gerçekleşir (Tay \& Yıldırım, 2009). Araştırmaya katılan öğretmenler ailenin değerleri kazandırma da rol model olması gerektiği, değerlerin uygulama ve davranışa dönüştürülmesi süreçlerini takip etmeleri gerektiğini belirtmişledir (Batmaz \& Erdoğan, 2019). Araştırmaya katılan öğretmenler değerler konusunda okulda yaşanan bazı sıkıntıların sebebini çocuğun aileden değerleri tam olarak öğrenerek gelmemesi olduğunu 
belirtmişlerdir. Temel değerlerin ailede yeterince verilmemesi, özellikle bazı ailelerde akademik başarının ön plana çıkması ve çocuğun ahlaki gelişiminin geri planda kalması değerlerin öğrenilmesinde ve davranışa dönüştürülmesinde problemlere neden olmaktadır (Bayırlı ve ark., 2020). Değerlerin öğrenilmesi hem bireysel hem toplumsal açıdan oldukça önemlidir. Araştırma bulgularından elde edilen sonuçlara göre değerler eğitiminden önce aile sonra okul sorumludur. Ayrıca okul ve ailenin bu süreçte işbirliği içinde olması ve birbirini desteklemesi gerekmektedir (Yıldırım ve ark., 2017).

Araştırmaya katılan öğretmenler öğrenciler okula başladıklarında öncelikle dürüstlük ve saygı değerlerine sahip olmaları gerektiği düşüncesindedir. Öğretmenler değerler eğitiminin önemini vurgulamışlar ve özellikle saygı değerinde problem yaşandığını belirtmiş̧lerdir (Bayırlı, Doruk \& Tüfekçi, 2020). Öğretmen, öğrenci ve velilerin katıldığı araştırma sonuçlarına göre aile de kazandırıldığı düşünülen başlıca değerler sevgi, saygı ve dürüstlüktür (Yıldırım, Becerikli \& Demirel, 2017).

Araştırma da yer alan veliler değer kazandırma da en çok Türkçe, sosyal bilgiler, din kültürü ve ahlak bilgisi derslerinin etkili olduğunu ifade etmişlerdir. Okul öncesi öğretmenleri değerler eğitimine en çok Türkçe ve drama etkinliklerinde yer verdiklerini belirtmişlerdir (Uzun \& Köse, 2017). Kurtdede-Fidan (2013) yılında yaptığı araştırma sonuçlarına göre sosyal bilgiler dersinin çocuklara değer bilinci kazandırma da ve değerleri öğretme de etkili olduğunu bulmuştur. Araştırmaya katılan öğretmenler sosyal bilgiler dersinin değerleri doğrudan kazandırma da etkili olduğunu belirtmişlerdir (Yiğittir \& Öcal, 2011).

Araştırma sonuçlarına göre dürüstlük, saygı ve sevgi değerlerinin öncelik verilmesi gereken değerler olarak ön plana çıktığı görülmektedir. Hem öğretmenler hem veliler öncelikli değerler olarak bu konuda aynı fikirdedirler. Kazandırmakta zorluk çekilen değerlere öğretmenler dürüstlük, saygı ve paylaşma değerlerini belirtirken veliler ise dürüstlük ve sorumluluk değerlerini söylemişlerdir. Araştırmaya katılan öğretmenler ve veliler birbirlerinden en çok dürüstlük, sevgi ve saygı değerlerini öğretmelerini beklemektedirler. Araştırma bulgularına göre değer öğretiminde en çok model olma, öğüt verme ve yaşantılardan örnekler verme yöntemleri kullanılmaktdır. Değer eğitiminde ilk olarak ailenin daha sonra okulun etkili olduğu ifade edilmiştir. 


\section{Öneriler}

Öğretmenler ve veliler kazandırmakta en çok zorluk çektikleri değer olarak dürüstlük değerini belirtmişlerdir. Bu bulgu dikkate alınarak özellikle dürüstlük değerinin vurgulandığı sınıf içi etkinlikler uygulanabilir.

Öğretmenlerin ve velilerin değerler konusunda birbirinden karşılıklı beklentileri dikkate alınarak işbirliği yapılabilir.

Aileleri bilinçlendirmek için değerler eğitimi konusunda seminerler ve bilgilendirme toplantıları yapılabilir. Aileleri değerler eğitimi sürecine dahil etmek için okul ve sınıf etkinlikleri düzenlenebilir.

Öğretmenler değerler eğitimi konusunda velilerin düşünce ve beklentilerini belirlemek için çeşitli anketler uygulayabilir ve bu sonuçlara göre ders planlarına değerlerle ilgili çeşitli aktiviteler ekleyebilir.

\section{Kaynakça}

Acat, M. B., \& Aslan, M. (2011, 08-10 Eylül). İlköğretim okullarındaki öğrencilere kazandırlması gereken değerler [Sempozyum]. 20. Ulusal Eğitim Bilimleri Kurultayı, Burdur, Turkey.

Acun, İ., Yücel, C., Önder, A., \& Tarman, B. (2013). Değerler: Kim ne kadar değer veriyor?. Uşak Üniversitesi Sosyal Bilimler Dergisi, 6 (1), 191-206.

Altan, M. Z. (2011). Çoklu zekâ kuramı ve değerler eğitimi. Pegem Eğitim ve Öğretim Dergisi, 1(4), 53-57.

Aktepe, V., \& Yalçınkaya, E. (2016). Okul ortamında değerler eğitiminin öğrenci görüşlerine çeşitli değişkenler açısından incelenmesi. Ahi Evran Üniversitesi Kırşehir Eğitim Fakültesi Dergisi (KEFAD), 2 (17), 113-131.

Akbaş, O. (2004). Türk milli eğitim sisteminin duyuşsal amaçlarının ilköğretim 11. kademedeki gerçekleşme derecesinin değerlendirilmesi (Yayımlanmamış Doktora Tezi). Gazi Üniversitesi, Eğitim Bilimleri Enstitüsü, Ankara.

Akbaş, O. (2008). Değerler eğitimi akımlarına genel bir bakış. Değerler Eğitimi Dergisi, 6 (16), 9-27.

Arpacı, M. (2014). Öğretmen ve velilerin DKAB dersinde değerler ve değerler eğitimi hakkindaki görüşleri. Marife Dini Araşttrmalar Dergisi, 14(2), 107-121.

Aslan, C. (2019). Value priorites of teacher candidates: using a scaling technique for value ranking. Journal of Education and Future, 17, 53-63.

Aslan, M. (2011). İlkögrretimde karakter eğitimi ve öğrencilere kazandırılması gereken değerler (Yayımlanmamış Yüksek Lisans Tezi). Eskişehir Osmangazi 
Üniversitesi, Eğitim Bilimleri Enstitüsü, Eskişehir.

Aslan, R. (2007). Öğretmen görüşlerine göre ilköğretim birinci basamaktaki öğrencilerin temel bilgi, beceri ve değerleri kazanma düzeyleri (Yayımlanmamış Yüksek Lisans Tezi). Eskişehir Anadolu Üniversitesi, Eğitim Bilimleri Enstitüsü, Eskişehir.

Ateş, F. (2013). Illkokul ve ortaokul öğretmenlerinin değerler eğitimi ve uygulamalarına yönelik görüşleri üzerine nitel bir çallş̧ma (Yayımlanmamış Yüksek Lisans Tezi). Yeditepe Üniversitesi, Eğitim Bilimleri Enstitüsü, İstanbul.

Aydın, M. (2011). Değerler, işlevleri ve ahlak. Eğitime Baklş Dergisi, 7 (19), 39-45.

Balcı, F. A. ve Yanpar, T. Y. (2010). İlköğretim öğretmenlerinin “değer” kavramına yükledikleri anlamlar. Hacettepe Üniversitesi Eğitim Fakültesi Dergisi, 39, 81-90.

Bardi, A., \& Schwartz, S. H. (2003). Values and behavior: Strenght and structure of relations. Personality and Social Psychology Bulletin, 29 (10), 1207- 1220.

Batmaz, O., \& Erdoğan, T. (2019). Sınıf öğretmenlerinin değerler eğitimine yönelik görüşleri. Kastamonu Eğitim Dergisi, 27(6), 2681-2692.

Baydar, P. (2009). İlköğretim beşinci sinıf sosyal bilgiler programında belirlenen değerlerin kazanım düzeyleri ve bu süreçte yaşanılan soruların değerlendirilmesi (Yayımlanmamış Yüksek Lisans Tezi). Çukurova Üniversitesi, Eğitim Bilimleri Enstitüsü, Adana.

Bayırlı, H., Doruk, O., \& Tüfekci, A. (2020). Öğretmenlerin değerler eğitimi hakkındaki görüşleri: Afyonkarahisar örneği. Eğitimde Nitel Araştırmalar Dergisi, 8(3), 865-894.

Berkant, H. G., Efendioğlu, A., \& Sürmeli, Z. (2014). Değerler eğitimine yönelik öğretmen görüşlerinin incelenmesi. Electronic Turkish Studies, 9(5).

Can, Ö. (2008). Dördüncü ve beşinci sinıf ögretmenlerinin sosyal bilgiler dersinde değerler eğitimi uygulamalarına ilişskin görüşleri (Yayımlanmamış Yüksek Lisans Tezi). Hacettepe Üniversitesi, Sosyal Bilimler Enstitüsü, Ankara.

Çağlayan, E. (2018). Değerler eğitimi ve uygulamalarına yönelik veli ve öğretmen tutumlarının değerlendirilmesi: Bingöl örneği (Yayımlanmamış Yüksek Lisans Tezi). Bingöl Üniversitesi, Sosyal Bilimler Enstitüsü, Bingöl.

Çelikkaya, T., Başarmak, U., Filoğlu, S., \& Şahin, B. (2014). Teacher-parents' relations in the efficiency of the value education. Procedia-Social and Behavioral Sciences, 116, 1106-1113.

Çelikkaya, T., \& Filoğlu, S. (2014). Sosyal bilgiler öğretmenlerinin değere ve değer eğitimine ilişkin görüşleri. Kuram ve Uygulamada Eğitim Bilimleri, 14(4), 1541-1556. 
Çelikkaya, T., \& Kürümlüoğlu, M. (2017). Veliler, öğrenciler ve sosyal bilgiler öğretmenlerinin programdaki değerlere ilişkin değer hiyerarşileri, gerekçeleri ve önerileri. Uluslararası Sosyal ve Eğitim Bilimleri Dergisi, 4(8), 243-264.

Çelikkaya, T., \& Yılmaz, T. (2017). Değerler eğitimine ilişkin öğretmen, öğrenci ve velilerin karşılıklı beklentileri. Researcher: Social Science Studies, 5(9), 395-416.

Çengelci, T., Hancı, B., \& Karaduman, H. (2013). Okul ortamında değerler eğitimi konusunda öğretmen ve öğrenci görüşleri. Değerler Eğitimi Dergisi, 11(25), 33-56.

Clipa, O., \& Iorga, A.M. (2013). The role of school-family partnership on moral development. Procedia-Social and Behavioral Sciences, 76, 197-203.

Creswell, J. (2014). Research design: Qualitative, quantitative, and mixed methods approaches (4th ed.). Sage Publishing.

Dere, İ. \& Yavuzay, M. (2020). Sosyal bilgiler öğretmenlerine göre okulda değerler eğitimi: bir olgubilim çalı̧̧ması. Mehmet Akif Ersoy Üniversitesi Eğitim Fakültesi Dergisi, 56, 61-91.

Dinçer, B., \& Gözel, Ü. (2019). İlkokul programlarında (1-4) yer alan ve kazandırılması hedeflenen değerlere ilişkin sınıf öğretmenlerinin ve öğrenci velilerinin görüşlerinin incelenmesi. Değerler Eğitimi Dergisi, 17(38), 207-234.

Emiroğlu, S. (2011). Kitap tanıtımı, ailede, okulda, toplumda değerler psikolojisi ve eğitimi. Uludağ Üniversitesi Illâhiyat Fakültesi Dergisi, 20 (2), 215-217.

Eren, E. (2018). Okul öncesinde değerler eğitiminin program, ögretmen ve aile görüşleri açısından incelenmesi (Yayımlanmamış Yüksek Lisans Tezi). Bolu Abant İzzet Baysal Üniversitesi, Eğitim Bilimleri Enstitüsü, Bolu.

Erikli, S. (2016). Development and implementation of a values education program for pre-school children (Yüksek Lisans Tezi). Middle East Technical University, The Graduate School Of Social Sciences, Ankara.

Gür, Ç., Koçak, N., Şirin, N., Şafak, M., \& Demircan, A. (2015). İlköğretim öğretmenlerinin değerler eğitimine ilişkin görüşleri ve karşılaştıkları güçlüklerin incelenmesi: Ankara örneği. Asya Öğretim Dergisi, 3(1), 78-91.

Halstead, J. M. (1996). Values and values education in schools. In J. M. Halstead \& M. J. Taylor (Eds.). Values in education and education in values. The Falmer Press.

Hood, K. L. (2011). Character education and parental involvement: Impact on academic achievement (Master Thesis). Rowan University.

Kalın, Ö. U. (2017). Sosyal bilgiler öğretmen adaylarının değer hiyerarşisi. Mustafa Kemal Üniversitesi Sosyal Bilimler Enstitüsü Dergisi, 14(38), 29-44. 
Kara, B. (2017). Illkokul ve ortaokullarda değerler eğitimi uygulamalarına ilişkin ögretmen görüşleri (Yayımlanmamış Yüksek Lisans Tezi). Uşak Üniversitesi, Sosyal Bilimler Enstitüsü, Uşak.

Katılmış, A. (2017). Values education as perceived by social studies teachers in objective and practice dimensions. Educational Sciences: Theory and Practice, 17 (4), 1231-1254.

Kişi, Y. (2009). Illköğretim okulu yöneticilerinin veli ve çevre ile olan işbirliğine ilişkin veli algılarının çeşitli değişkenler açısından incelenmesi (Yayımlanmamış Yüksek Lisans Tezi). Yeditepe Üniversitesi, Sosyal Bilimler Enstitüsü, İstanbul.

Koç, R., \& Akdoğan, H. (2018). Çocuklara değer aktarımının önemi. International Journal of Social Science, 1(65), 1-16.

Kurtdede- Fidan, N. (2009). Öğretmen adaylarının değerler eğitimine ilişkin görüşleri. Kuramsal Eğitimbilim, 2 (2), 1-18.

Kurtdede Fidan, N. (2013). Sosyal bilgiler dersinde değerler eğitimi: Nitel bir araştırma. The Journal of Academic Social Science Studies, 6(3), 361-388.

Merriam, S. B. (2013). Nitel araştırma desen ve uygulama için bir rehber, Nobel Yayınlar1, Ankara.

Miles, M. B. Ve Huberman, A. M. (1994). Qualitative data analysis: An expanded sourcebook. Sage.

Neslitürk, S. (2013). Anne değerler ĕgitimi programının 5-6 yaş çocuklarının sosyal beceri düzeyine etkisi (Yayımlanmamış Doktora Lisans Tezi)., Selçuk Üniversitesi, Sosyal Bilimler Enstitüsü, Konya.

Oladipo, S. E. (2009). Moral education of the child: Whose responsibility? Journal of Social Sciences, 20(2), 149-56.

Pala, A. (2011). The need for character education. Internatıonal Journal Of Social Sciences And Humanity Studies, 3 (2), 23-32.

Patton, M.Q. (2001). Qualitative Research and Evaluation Methods. Sage Publishing.

Powell, D. R., Son, S.C., F. N., \& Juan. R. S. (2010). Parent school relationships and children's academic and social outcomes in public school pre-kindergarten. Journal of School Psychology, 48, 269-92.

Sağlam, A . (2016). Değerler eğitiminin öğrenci davranışlarına etkisinin veli görüşlerine göre incelenmesi. Türkiye Sosyal Araştırmalar Dergisi, 20 (3), 723-742.

Sarıkaya, M. (2019). Çocuk yetiştirme değerlerine ilişkin ebeveyn ve ergen 
görüşleri (Master's thesis) İstanbul Sabahattin Zaim Üniversitesi, Sosyal Bilimler Enstitüsü, İstanbul.

Sanger, M.N. \& Osguthorpe, R.D. (2013). Modeling as moral education: Documenting, analyzing, and addressing a central belief of preservice teachers. Teaching and Teacher Education, 29, 167-176.

Schwartz, S. H. (2006). Basic human values: Theory, measurement, and applications. Revue Francaise de Sociologie, 42, 249-88.

Selvitopu, A., Bora, V., \& Taş, A. (2015). Ortaöğretim öğrencilerine kazandırılması gereken değerlere ilişkin velilerin okuldan beklentileri. Kastamonu Ĕğitim Dergisi, 23(3), 979-94.

Şahin, A. (2011). Öğretmen algılarına göre etkili öğretmen davranışları. Ahi Evran Üniversitesi Kırşehir Eğitim Fakültesi Dergisi, 12(1), 239-259.

Tay, B. ve Yıldırım, K. (2009). Sosyal bilgiler dersinde kazandırılması amaçlanan değerlere ilişkin veli görüşleri. Kuram ve Uygulamada Eğitim Bilimleri, 9(3) 1499-1542.

Turan, S. \& Aktan, D. (2008). Okul hayatında var olan ve olması düşünülen sosyal değerler. Türk Eğitim Bilimleri Dergisi, 6 (2), 227-259.

Uzun, M. \& Köse, A. (2017). Okul öncesi dönemde değerler eğitiminin uygulanmasına yönelik öğretmen görüşleri. Bayburt Eğitim Fakültesi Dergisi, 12 (23), 305-338.

Ünlü, İ., \& Kaşkaya, A. (2018). Sosyal bilgiler öğretmenlerinin değer eğitimine ilişkin görüşlerinin incelenmesi. Uluslararası Türkçe Edebiyat Kültür Eğitim Dergisi, 7(4), 2656-2679.

Whitbeck, L. B \& Gecas V. (1988). Value attributions and value transmission between parents and children. Journal of Marriage and Family, 50(3), 829-40.

Yaka, Ş., Yalçın, D., \& Denizli, E. (2014). Okul öncesi eğitimde verilecek öncelikli değerlere ilişkin veli görüşleri. Değerler Eğitimi Dergisi, 28(12), 169-92.

Yaşar, Ş., \& Çengelci, T. (2012). Sosyal bilgiler dersinde değerler eğitimine ilişkin bir durum çalışması. Uluslararası Avrasya Sosyal Bilimler Dergisi, 3(9), 1-23.

Yaşaroğlu, C. (2016). Cooperation and importance of school and family on values education. European Journal of Multidisciplinary Studies, 1(2), 66.

Lakshmi, V. \& Paul, M. (2018). Value education in educational institutıons and role of teachers in promoting the concept. International Journal of Educational science and Research, 8 (4), 29-38.

Lazarides, R., Harackiewicz, J., Canning, E., Pesu, L., \& Viljaranta, J. (2015). The role of parents in students' motivational beliefs and values. In C. Rubie-Da- 
vies, J. Stephens, \& P. Watson (Eds.), The Routledge International Handbook of Social Psychology of the Classroom. Routledge.

Lovat, T. (2005). Values education and teachers' work: A quality teaching perspective. New Horizons in Education, 112, 1-13.

Yıldırım, A. Şimşek, H. (2011). Sosyal bilimlerde nitel araştırma yöntemleri. Seçkin Yayınları.

Yıldırım, S. G., Becerikli, S., \& Demirel, M. (2017). Farklı bakış açılarına göre sosyal bilgiler dersinde değerler eğitimi. İlköğretim Online, 16(4), 1575-1588.

Yiğittir, S., \& Öcal, A. (2011). High school history teachers' views on values and values education. KMU Journal of Social and Economic Research, 13(20), 117-124.

Yiğittir, S. (2010). İlköğretim öğrenci velilerinin okullarda kazandırılmasını arzuladığı değerler. Değerler Ĕgitimi Dergisi. 8 (19), 207-223. 
Extended Abstract

\title{
School - Family Cooperation in the Value Education Process: A Qualitative Study
}

\author{
Zeliha AKIN, Corresponding Author, Teacher. \\ Republic of Turkey National Education Ministry, Ankara / Turkey. \\ zelis38@gmail.com \\ https://orcid.org/0000-0001-9430-1039 \\ Prof.Dr. Ergün ÖZTÜRK, Professor. \\ Erciyes University, Faculty of Education, Kayseri / Turkey. \\ erg2424@gmail.com \\ https://orcid.org/0000-0002-4800-8437
}

Article Type: Research Article

https://doi.org/10.34234/ded.741279

Received Date: 11.04 .2021

Accepted Date: 20.06.2021

Published Date: 25.12.2021

\section{Introduction}

Values shape our lives by influencing our choices, decisions, and relationships. Values are positive personal and social preferences (Halstead, 1996), desired and expected behavior patterns (Aydın, 2011), criteria that affect our perspective on life and shape our decisions and lifestyle (Turan \& Aktan, 2008; Emiroğlu, 2011; Erikli, 2016; Çağlayan, 2018), motivational tools (Bardi \& Schwartz, 2003), that can be defined as standards or accepted by most people.

Family is the first institution that transfers values, behaviors, and attitudes to the child. Parents are responsible for teaching the values and beliefs of society 
(Whitbeck \& Gecas. 1988). Having a good relationship with the child, the behavior of the family when the child makes a mistake, explaining the moral rules to the child, and expressing their expectations to the child about moral values facilitate the value learning process (Oladipo, 2009).

One of the most important ways of teaching and keeping values alive is education. Values education enables individuals to be aware of their own characteristics, to be in harmony with their feelings, thoughts, behaviors, and attitudes, to make judgments about what is right and what is wrong, and to shape their behavior (Akbaş, 2008).

The education process that starts in the family continues with the society and the school, and behaviors are tried to be reinforced and made permanent (Kara, 2017). At school, the child has the opportunity to learn values such as respect, love, tolerance, helpfulness, sensitivity, and responsibility, and transform them into behavior. For this reason, the school environment should be organized not only to teach information but also to teach values (Çengelci, Hanc1 \& Karaduman, 2013). Teachers have an important responsibility in values education. The teacher should have sufficient knowledge and skills and be a good model in value education (Aktepe, Yalçınkaya, 2016).

Parents' participation in the education process is effective in both gaining positive behavior and maximizing the benefit of the lessons. The purpose of school-family cooperation is to minimize the negative character traits seen in the child such as; stubbornness, selfishness, laziness, lying, and showing incompatible behaviors, and help him or her to develop positive character traits instead of eliminating such behaviors (Clipa \& Iorga. 2012).

This research aims to reveal teachers 'and parents' views on the school-family cooperation in the value teaching process. To achieve this goal, answers to the following questions were sought:

- What are the perceptions of teachers and parents towards values education?

- What are the values that teachers and parents prioritize?

- Which values parents and teachers have difficulty in teaching?

- What are the expectations of teachers and parents from each other on values education?

- What are the most common approaches, strategies, or methods parents and teachers use while teaching values? 


\section{Method}

In this study, the qualitative research design was applied to provide in-depth information about the importance of school and family cooperation in values education. In qualitative research, events and phenomena are examined in detail within their natural environments (Yıldırım \& Şimşek, 2011). Qualitative research begins with an assumption about a complex problem about the person or group that needs to be investigated. Qualitative research takes time, requires in-depth analysis and description (Creswell, 2014).

\section{Study Group}

Participants in this study were chosen by the purposeful sampling method. In the purposeful sampling method, detailed descriptions and in-depth research are provided by selecting the facts and situations that have rich information about the event (Patton, 2001). The study group consists of 10 teachers of the 5thgrade classes and 10 parents who have students in 5th grade at a public school in Kayseri.

\section{Collection of Data}

In this study, data were collected using a semi-structured interview form. The interview form was prepared by taking the opinions of the field experts and was finalized by making the necessary regulations. In this study, interviews were conducted via this form to determine the perceptions of teachers and parents about school-parent cooperation in the value education process. A total of 10 teachers and 10 parents were interviewed one by one and each interview took approximately 25 minutes. The interviews were recorded by audio recording, then the audio recording of each interview was analyzed, and the codes and themes obtained are presented in the tables.

\section{Findings}

In the interviews, the teachers expressed their value definitions in different ways. The value definition codes of teachers are as follows; form of existence, positive characteristics, moral criteria, rules to belong to society, valuable things, ethical rules and behaviors, human qualities, beneficial issues, transferring feelings and thoughts to life, and common forms of behavior. As a result of the interviews 
with the parents, their definitions are moral criteria, valuable things, the sum of positive features, human qualities, judgments, feelings, honesty, love, and respect. According to teachers, honesty and respect are the most important values. Whereas for parents; respect and love are more important than others.

While teachers struggle to teach values of honesty, respect, and sharing, parents have difficulty in teaching honesty. The teachers who participated in the research state that they expect parents to teach honesty and respect. Parents expect teachers to teach respect and love. Teachers mostly rely on the role modeling method. While parents mostly use the method of advising on value education. According to the results of the research, teachers think that values can be gained mostly in families and schools. Teachers stated that when students start school, they must first learn the values of honesty and respect. The parents stated that Turkish, Social Studies and Religion lessons are effective in teaching value. According to teachers' views, a teacher should give more importance to the values of honesty, respect, and love and teach the students these values first.

\section{Discussion and Conclusions}

According to research results, value definitions of the parents and teachers are similar to the value definitions in the literature review. Value definitions are defined as the sum of positive characteristics (Aydin, 2011), moral criteria (Turan \& Aktan, 2008; Emiroğlu, 2011; Erikli, 2016; Çağlayan, 2018), and rules that should exist in social life (Koç \& Akdoğan, 2018).

According to the research results, values prioritised by teachers are honesty, respect and love while the parents primarily prefer good morals, love and respect. The opinions of the teachers largely overlap with the results of different studies in the field (Çengelci, Hanc1 \& Karaduman 2013, Dere \& Yavuzay 2020, Uzun \& Köse 2017). According to the results of the study conducted by Tay and Yildırım (2009), the values that parents attach importance to are listed as; respect (80), honesty (47), and love (41) come to the fore.

As a result of the research related to teachers' opinions the values that are difficult to teach are honesty, respect, sharing, fairness, responsibility, helpfulness, self-respect, loyalty, hard work, tolerance and cooperation, while the parents stated that they had the most difficulty in teaching the values of honesty and good morals. In the researches, it is stated that the value that teachers have the most difficulty in teaching at school is responsibility. (Aslan, 2007; Aktepe \& Yalçınkaya, 2016; Çengelci et al., 2013). 
According to the findings of the study, parents and teachers expect each other to primarily teach the values of honesty, respect and love. According to the study of Selvitaş1, Bora and Taş (2015), the value of respect comes first among the values parents expect to be taught to their children at school. According to the study conducted by Yiğittir (2010), the values that parents most want to be taught at school are honesty and respect.

Another result reached in the research is that teachers mostly use the method of being a role model, giving examples from experiences, benefiting from books and movies, and parents mostly using the method of giving advice, being a role model and giving examples from life. According to the research conducted by Selvitaş1, Bora and Taş (2015), parents mostly used the methods of modeling and giving advice while teaching value.

The teachers who participated in the research stated that values can be learned mostly in the family and at school. The family is the place where the child acquires values first. Children learn basic behaviors by observing the behavior of their parents. According to the results of the research, the teachers indicated that the family has an important role in value education and that it is the most important factor determining the value of the child (Akbaş, 2004).

The teachers think that when students start school, they should first have acquired the values of honesty and respect. According to the research results in which teachers, students and parents participated, the main values that are expected to be gained in the family are love, respect and honesty (Yildirım, Zenginli \& Demirel, 2017).

The parents participated in the research stated that Turkish, Social Studies, Religious Studies are the most effective subjects in teaching values. Especially, Social Studies subject is effective in raising awareness and facilitating teaching values to children (Kurtdede -Fidan, 2013).

\section{Sugesstions}

- In-service trainings can be organized for teachers regarding values education.

- Teachers and families can cooperate on values education.

- School and classroom activities can be organized to involve families in the values education process. 
Etik Beyan / Ethical Statement: Bu çalı̧̧manın hazırlanma sürecinde bilimsel ve etik ilkelere uyulduğu ve yararlanılan tüm çalışmaların kaynakçada belirtildiği beyan olunur. / It is declared that scientific and ethical principles have been followed while carrying out and writing this study and that all the sources used have been properly cited.

Finansman / Funding: Yazarlar, bu araştırmayı desteklemek için herhangi bir dış fon almadıklarını kabul ederler. / The authors acknowledge that they recevied no external funding in support of this research.

Yazar (lar) / Author (s): Zeliha AKIN, Ergün ÖZTÜRK

Yazar Katkıları / Author Contributions: Zeliha AKIN (\%50), Ergün ÖZTÜRK (\%50)

Çıkar Çatışması / Competing Interests: Yazarlar, çıkar çatışması olmadığını beyan ederler. / The authors declare that they have no competing interests. 